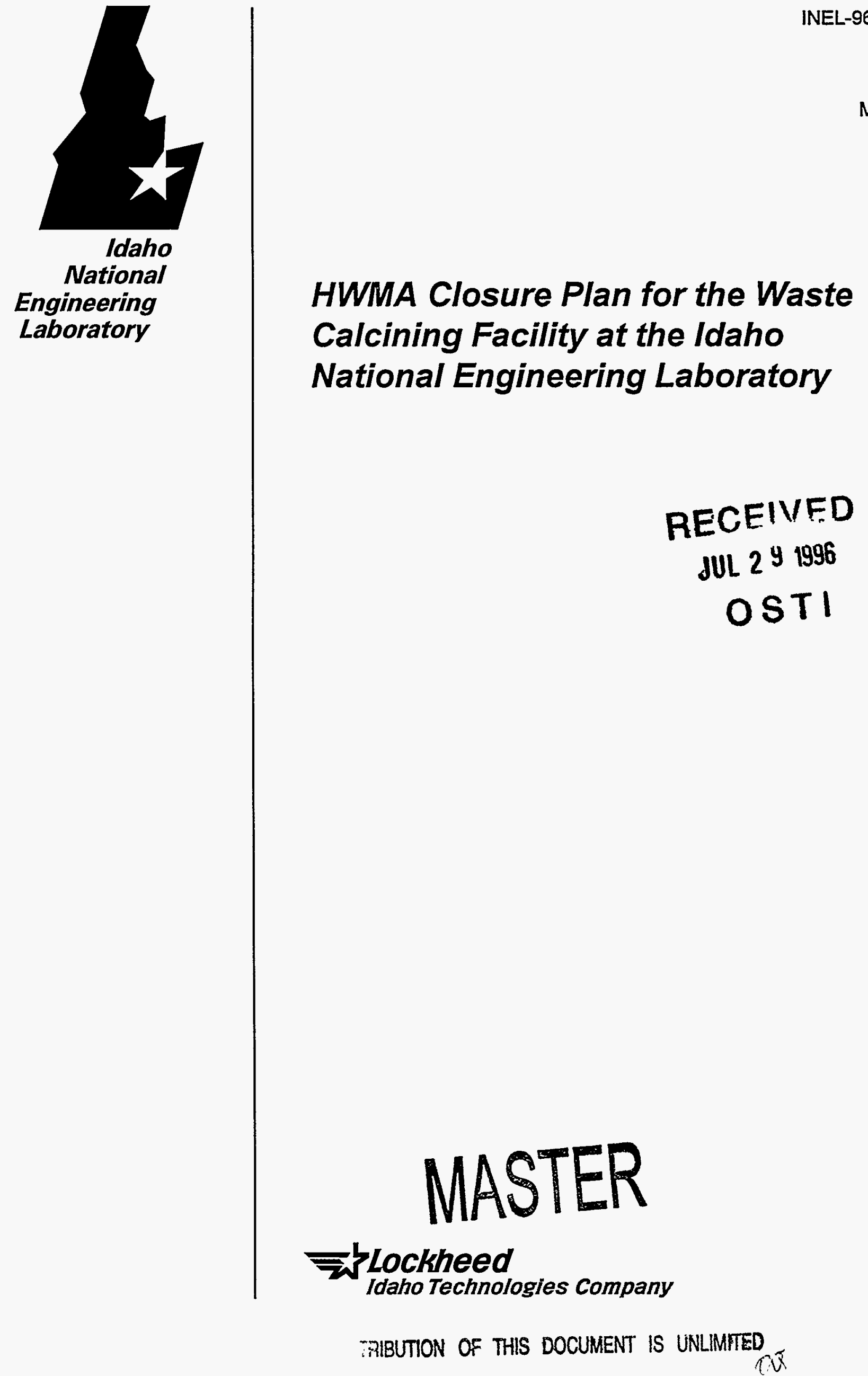

May 96 


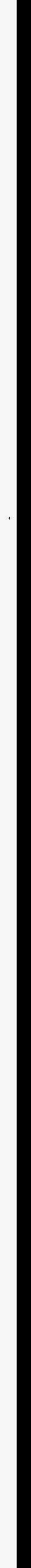


INEL-96/0189

\title{
HWMA Closure Plan for the Waste Calcining Facility at the Idaho National Engineering Laboratory
}

\author{
Published May 1996 \\ Idaho National Engineering Laboratory \\ Lockheed Idaho Technologies Company \\ Idaho Falls, Idaho 83415
}

Prepared for the

U.S. Department of Energy

Under DOE Idaho Operations Office

Contract DE-AC07-94ID13223 
. 


\section{CONTENTS}

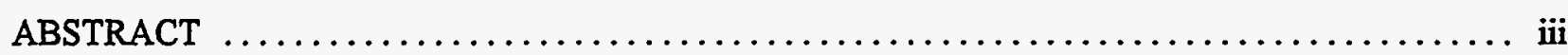

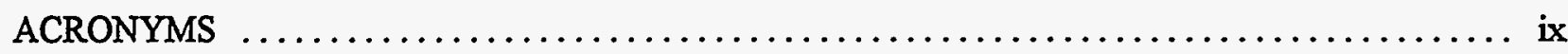

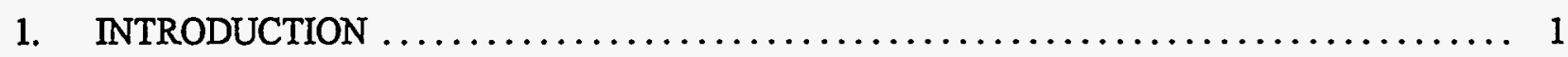

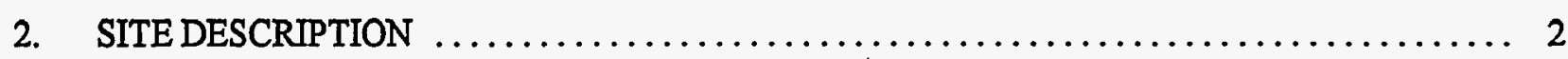

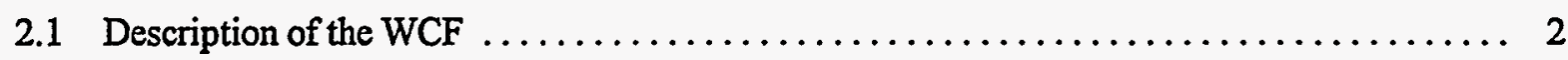

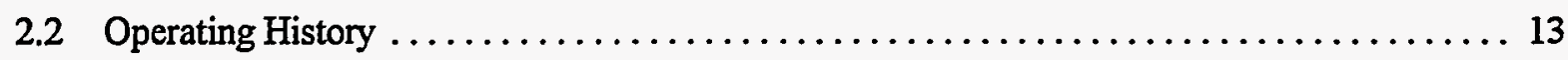

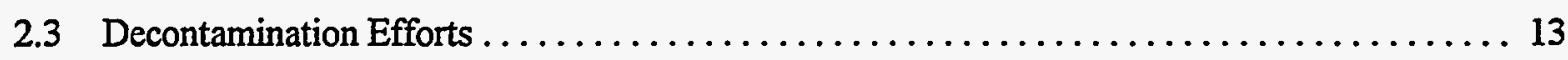

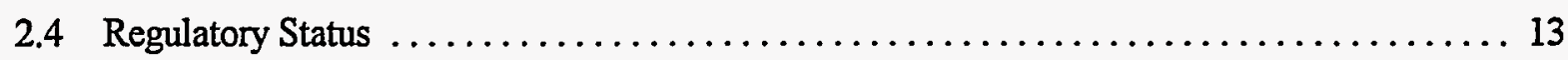

Related Issues-CERCLA $\ldots \ldots \ldots \ldots \ldots \ldots \ldots \ldots \ldots \ldots \ldots \ldots \ldots \ldots \ldots \ldots \ldots \ldots \ldots \ldots, 14$

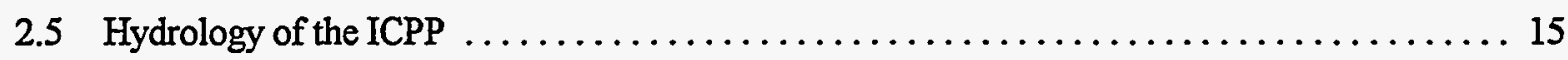

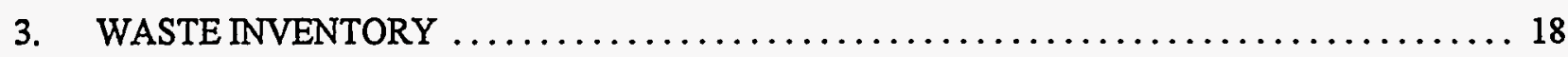

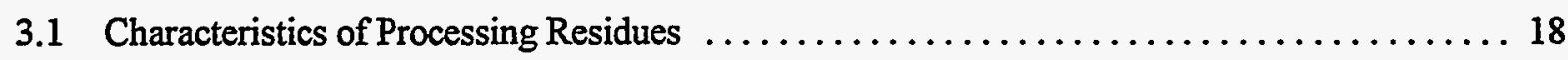

3.2 Quantities of Process Residues .................................... 20

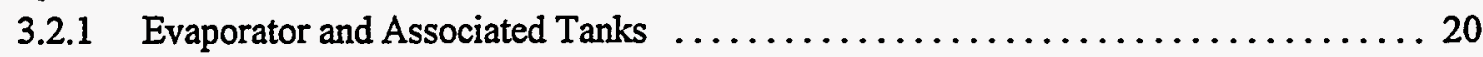

3.2 .2 HEPA Filters ........................................... 20

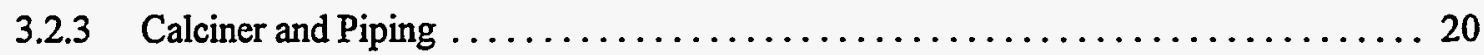

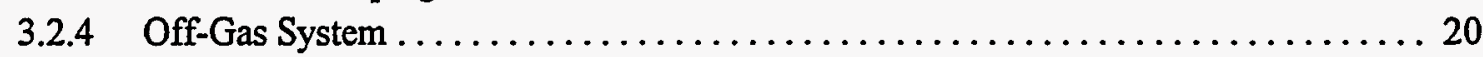

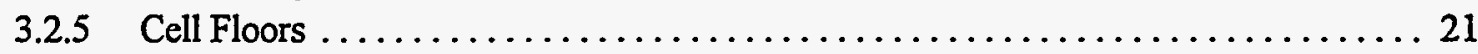

3.2.6 Product Transfer Piping and Off-Gas Ducts $\ldots \ldots \ldots \ldots \ldots \ldots \ldots \ldots \ldots \ldots \ldots \ldots \ldots$

3.3 Lead Shielding, Instruments Containing Mercury, and Equipment Oil ............. 21

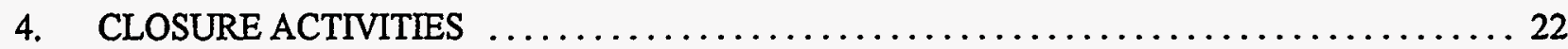

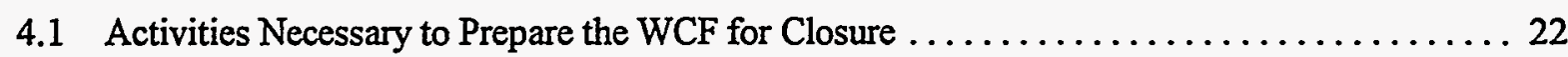

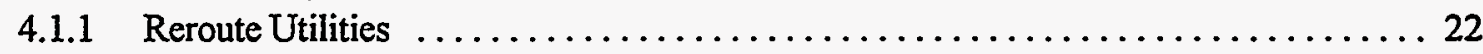

4.1.2 Above Grade Equipment Dismantlement and Grouting ................ 22

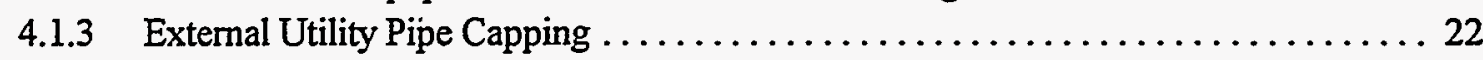

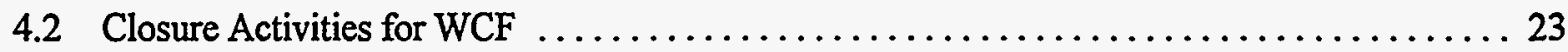

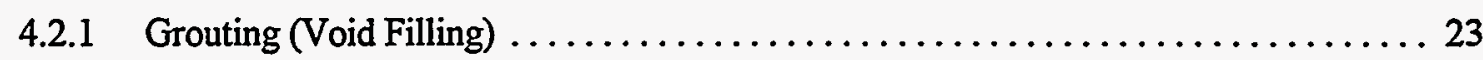

4.2.1.1 Capping of the Waste Piping. ......................... 23 
4.2.1.2 Vessel Grouting. ................................... 23

4.2.1.3 Cell Grouting. ..................................... 23

4.2.1.4 Contamination Release Concerns. ....................... 23

4.2.1.5 Description of the Superstructure Removal and Placement. .......... 25

4.2.2 Description of the Cap ................................... 26

4.2.3 Inspections and Monitoring During Pre-Closure and Closure $\ldots \ldots \ldots \ldots \ldots 26$

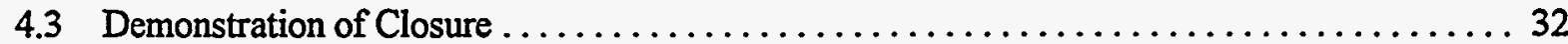

4.3.1 Closure Performance Standards . . . . . . . . . . . . . . . . . . . . . . . . 32

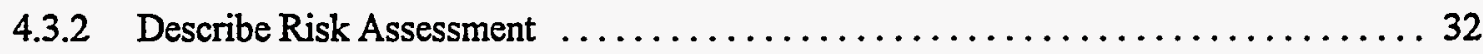

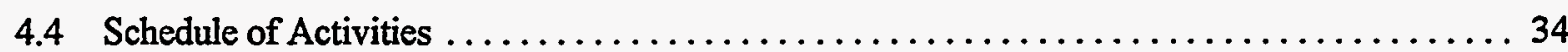

4.4.1 WCF Unit Closure Schedule ...................................... 34

4.4 .2 Request for Time Extension ................................. 34

4.4.3 Amendments To The Closure Plan ............................ 34

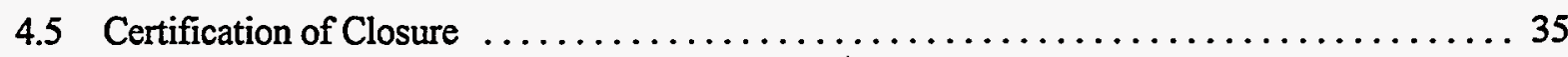

4.6 Survey Plat and Certification by Professional Land Surveyor $\ldots \ldots \ldots \ldots \ldots \ldots \ldots \ldots$

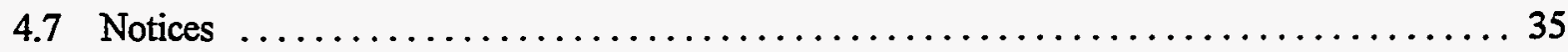

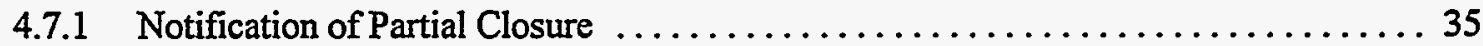

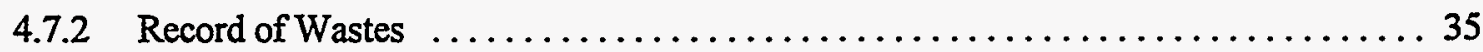

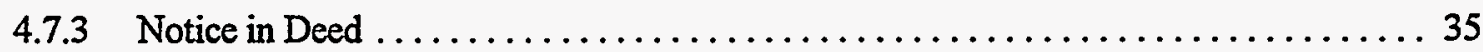

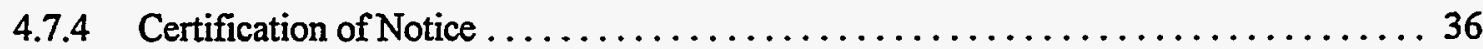

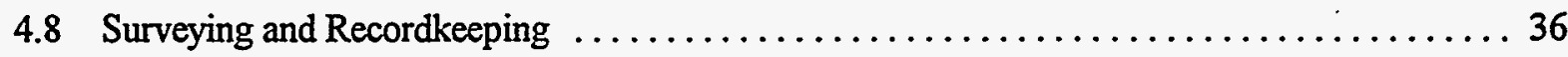

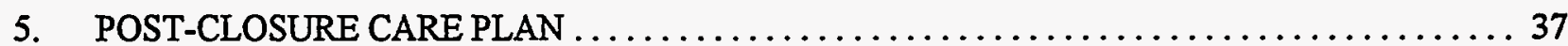

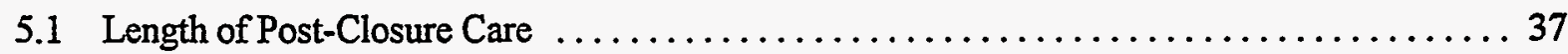

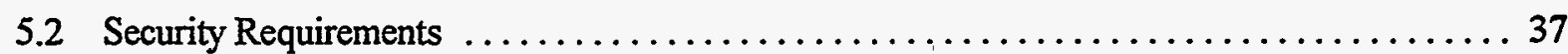

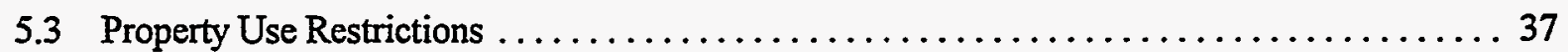

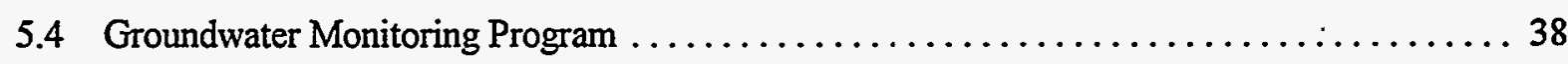

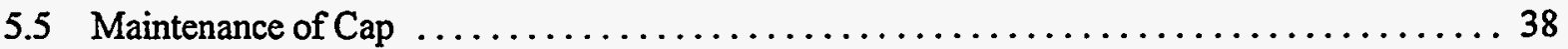

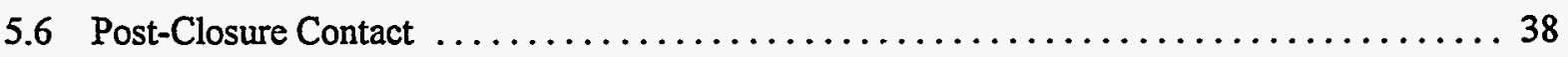

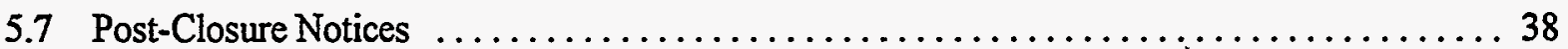


5.8 Certifications of Completion of Post-Closure Care $\ldots \ldots \ldots \ldots \ldots \ldots \ldots \ldots \ldots \ldots \ldots \ldots \ldots \ldots \ldots$

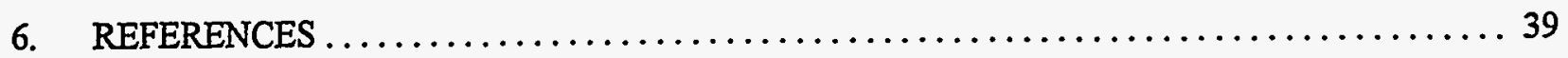

\section{TABLES}

1. Listed wastes determined to have been used at ICPP $\ldots \ldots \ldots \ldots \ldots \ldots \ldots \ldots \ldots$

\section{FIGURES}

1. Map of the INEL depicting the location of the ICPP $\ldots \ldots \ldots \ldots \ldots \ldots \ldots \ldots \ldots \ldots \ldots \ldots$

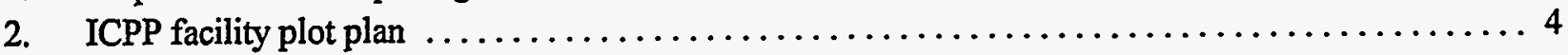

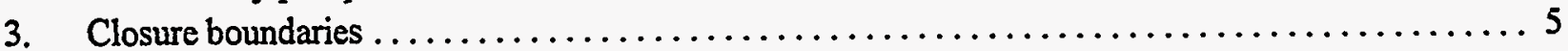

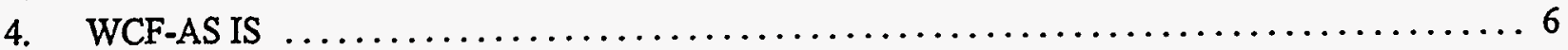

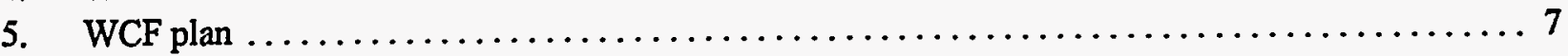

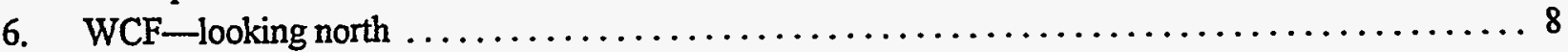

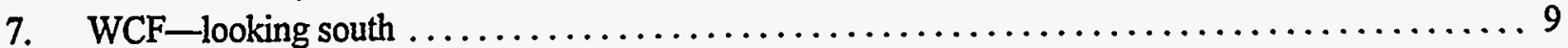

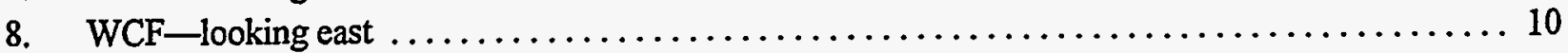

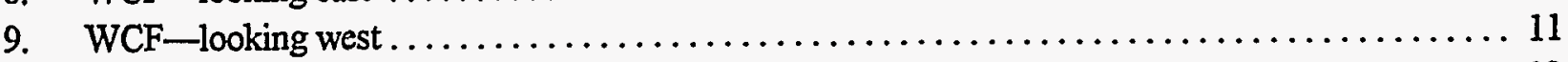

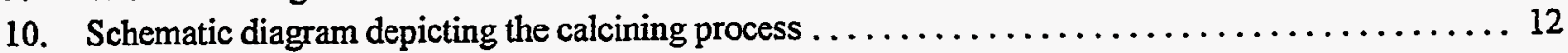

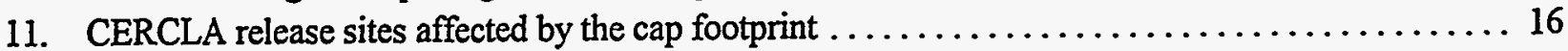

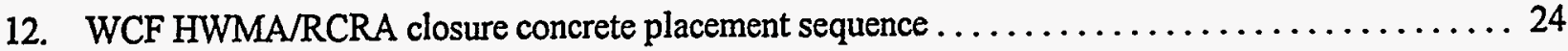

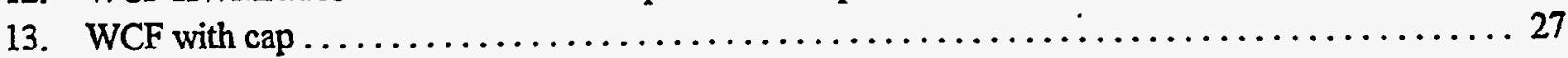

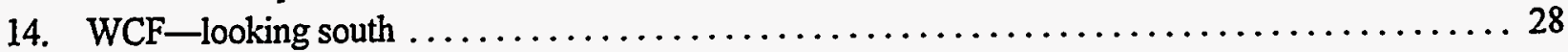

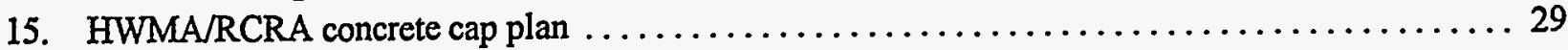

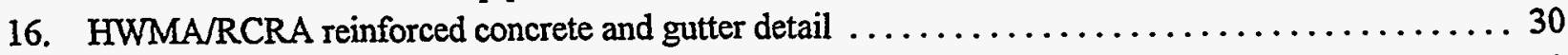

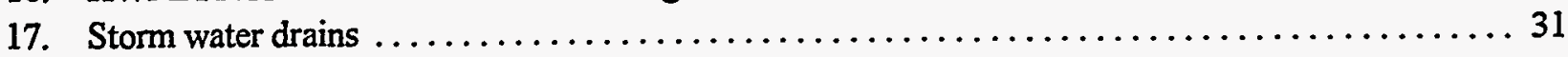

\section{DISCLAIMER}

This report was prepared as an account of work sponsored by an agency of the United States Government. Neither the United States Government nor any agency thereof, nor any of their employees, makes any warranty, express or implied, or assumes any legal liability or responsibility for the accuracy, completeness, or usefulness of any information, apparatus, product, or process disclosed, or represents that its use would not infringe privately owned rights. Reference herein to any specific commercial product, process, or service by trade name, trademark, manufacturer, or otherwise does not necessarily constitute or imply its endorsement, recommendation, or favoring by the United States Government or any agency thereof. The views and opinions of authors expressed herein do not necessarily state or reflect those of the United States Government or any agency thereof. 


\section{DISCLAIMER}

Portions of this document may be illegible in electronic image products. Images are produced from the best available original document. 



\section{ACRONYMS}

ALARA as low as reasonably achievable

APS Atmospheric Protection System

ARAR applicable, relevant, and appropriate requirements

CERCLA Comprehensive Environmental Response, Compensation and Liability Act

CSSF Calcined Solid Storage Facility

CPP Chemical Processing Plant

DOE U.S. Department of Energy

DOE-ID U.S. Department of Energy-Idaho Operations Office

EPA U.S. Environmental Protection Agency

FFA/CO Federal Facility Agreement/Consent Order

HWMA Hazardous Waste Management Act

HEPA high efficiency particulate air

ICPP Idaho Chemical Processing Plant

IDAPA Idaho Administrative Procedures Act

IDHW Idaho Department of Health and Welfare

INEL Idaho National Engineering Laboratory

LITCO Lockheed Idaho Technologies Company

NWCF New Waste Calcining Facility

PEW Process Equipment Waste

RCRA Resource Conservation and Recovery Act

ROD Record of Decision

TSD Treatment, Storage, and/or Disposal 
USGS

WAG

WCF
United States Geological Survey

Waste Area Group

Waste Calcining Facility 


\section{RCRA Closure Plan for the Waste Calcining Facility at the Idaho National Engineering Laboratory (Draft)}

\section{INTRODUCTION}

The Waste Calcining Facility (WCF) calcined and evaporated aqueous wastes generated from the reprocessing of spent nuclear fuel. The calciner operated from 1963 to 1981, primarily processing high level waste from the first cycle of spent fuel extraction. Following the calciner shutdown the evaporator system concentrated high activity aqueous waste from 1983 until 1987. In 1988, U.S. Department of Energy Idaho Operations Office (DOE-ID) requested interim status for the evaporator system, in anticipation of future use of the evaporator system. The evaporator system has not been operated since it received interim status. At the present time, DOE-ID is completing construction on a new evaporator at the New Waste Calcining Facility (NWCF) and the evaporator at the WCF is not needed. The decision to "not use" the WCF evaporator requires Lockheed Idaho Technologies Company (LITCO) and DOE-ID to close these units.

It is not practical to clean close the WCF units due to the radiation fields in the cells, maintain as low as reasonably achievable (ALARA) worker exposures, generation of additional mixed waste, and the time and cost to reduce the high radiation fields associated with the process residues in the units and containment cells. After a detailed evaluation of closure options, LITCO and DOE-ID have determined the safest option is to fill the voids (grout the vessels, cells and waste pile) and close the WCF to meet the requirements applicable to landfills. The WCF will be covered with a concrete cap that will meet the closure standards identified in IDAPA 16.01.05.009 (40 CFR 265.111 and 265.310). In addition, it was decided to apply these closure standards to the calcining system since it is contained within the WCF building. 


\section{SITE DESCRIPTION}

The Idaho National Engineering Laboratory (INEL) is located approximately 29 miles (mi) west of Idaho Falls, Idaho. The Idaho Chemical Processing Plant (ICPP) is situated on the south-central portion of the INEL site as indicated on Figure 1 and occupies an enclosed and secured area of approximately $1 \mathrm{~km}^{2}$ (250 acres). The WCF (building CPP-633) is located near the center of ICPP as shown on Figure 2.

The ICPP's primary mission is to safely and cost-effectively manage the radioactive and hazardous waste produced from past spent nuclear fuel processing activities. The WCF contains an evaporator tank system that includes several vessels contained in concrete vaults or cells, and their associated piping, pumps, and floor drains. The calcining process converted high-level radioactive liquid waste into a solid form for dry storage. The WCF converted over 15.2 million liters ( 4 million gallons) of high level liquid waste to less than $2,180 \mathrm{~m}^{3}\left(77,00 \mathrm{ft}^{3}\right)$ of calcine between 1963 and 1981 . All of the calcined product was transferred to interim storage at the Calcined Solid Storage Facility (CSSF) pending further treatment and ultimate disposition in a geological repository. The liquid wastes processed in the WCF contained varied amounts of hazardous constituents, as well as radiological contaminants.

\subsection{Description of the WCF}

The WCF boundaries encompassed by the closure activities are the outside walls and floors of the underground portion, the above ground structure, and includes the product transfer lines $8 \mathrm{~m}(26 \mathrm{ft}$ ) from the east wall and the liquid waste, ventilation, and utility piping out to the first valve box as indicated on Figure 3. The WCF is a heavily reinforced concrete structure with approximately $1,900 \mathrm{~m}^{2}\left(7,560 \mathrm{ft}^{2}\right)$ of total floor space made up of a ground level and two levels below grade, within a $21 \times 33 \mathrm{~m}(70 \times 108 \mathrm{ft})$ footprint as pictured in Figures 4 through 9. As shown, the processing levels are below grade in two banks of cells separated by common operating and access corridors. Non-radiation service areas are located in the above ground superstructure and are erected of concrete block and steel construction. The design and operation of the WCF utilized lead shielding in many of the below ground cells, pipe corridors, and sample and monitoring stations to protect workers from the high radiation fields. This shielding is located inside of cell walls or in areas heavily contaminated with radioactive constituents.

The interim status regulated units in the WCF are the evaporator tank system and the High Efficiency Particulate Air (HEPA) filter waste pile. The evaporator system is comprised of the following vessels; blend and hold tanks (WC-100 and -101), scrubber tank (WC-108), evaporator (WC-114), and the bottoms tank (WC-119) and their associated piping. Vessel WC-119 is a sump tank located in the lowest cell of the WCF and is currently used to collect steam condensate from building heating and rainwater from leaks in the roof that drip on the floor and is collected through open drains. The water collected in WC-119 may contain radionuclides and mercury (slightly above $0.2 \mathrm{mg} / \mathrm{l}$ ) and is transferred to the Process Equipment Waste (PEW) facility for treatment. The HEPA filter waste pile consists of five HEPA filter boxes in the filter cell.

The WCF closure activities will encompass additional equipment and tanks not listed on the Part $\mathrm{A}$ of the INEL permit, since they may contain process residues. The calciner and off-gas system include vessels WC-102, $-107,-110,-111,-112,-113,-130,-147,-148$, and on-line HEPA filters and their associated piping as depicted on Figure 10. 


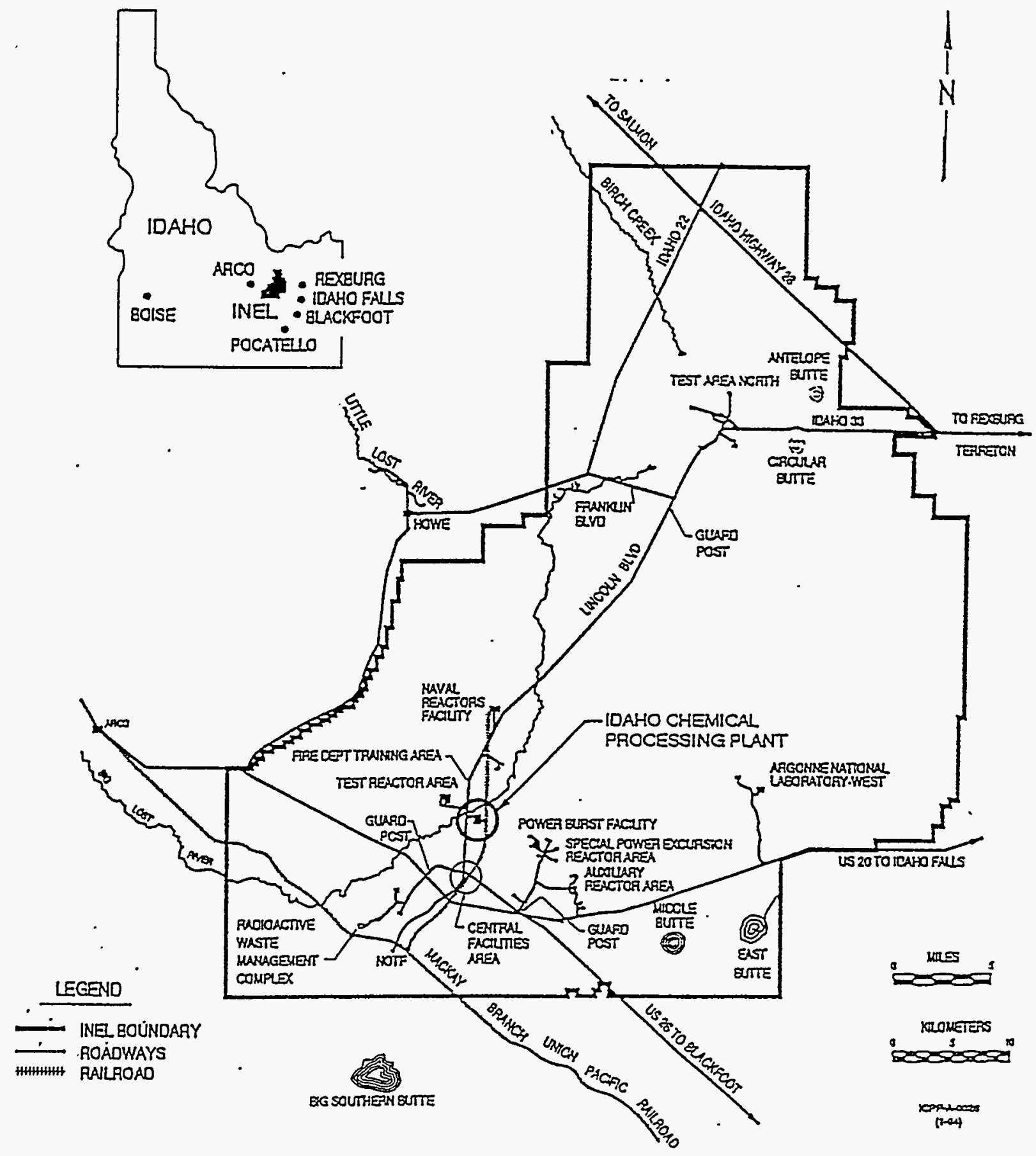

Figure 1. Map of the INEL depicting the location of the ICPP. 

(iv)

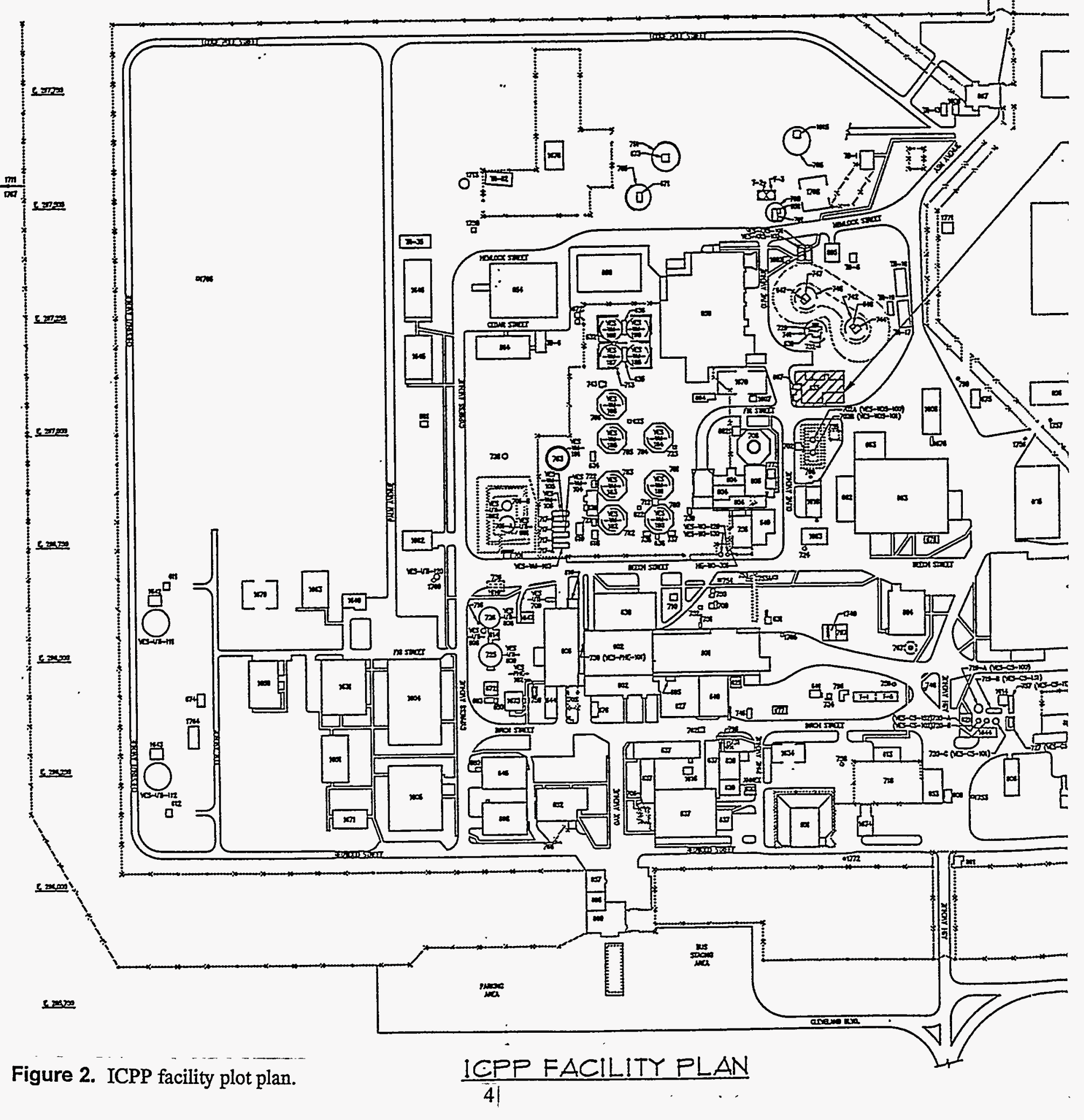




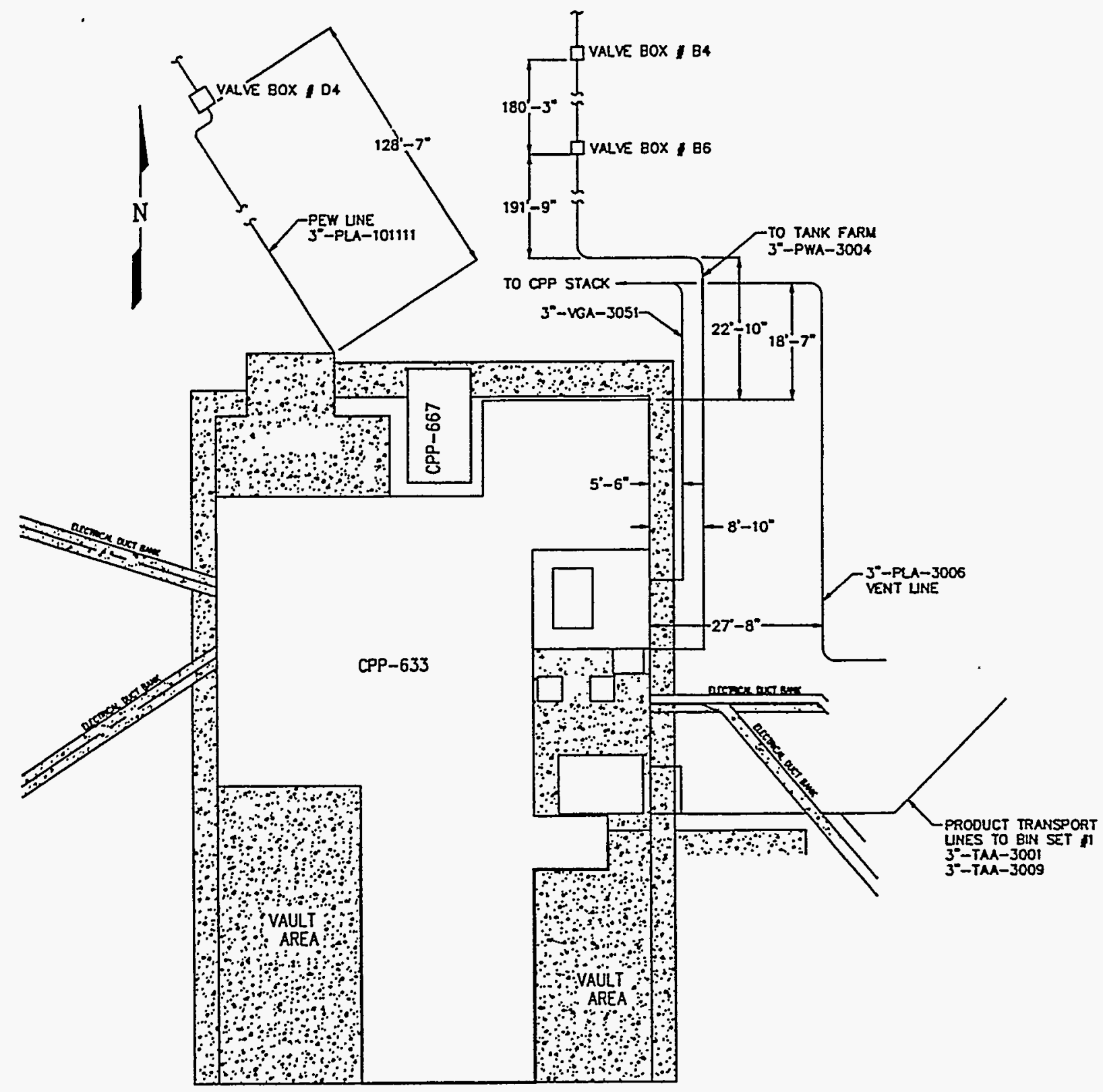

SCALE: $1^{-}=10^{\circ}-0^{*}$

Figure 3. Closure boundaries. 


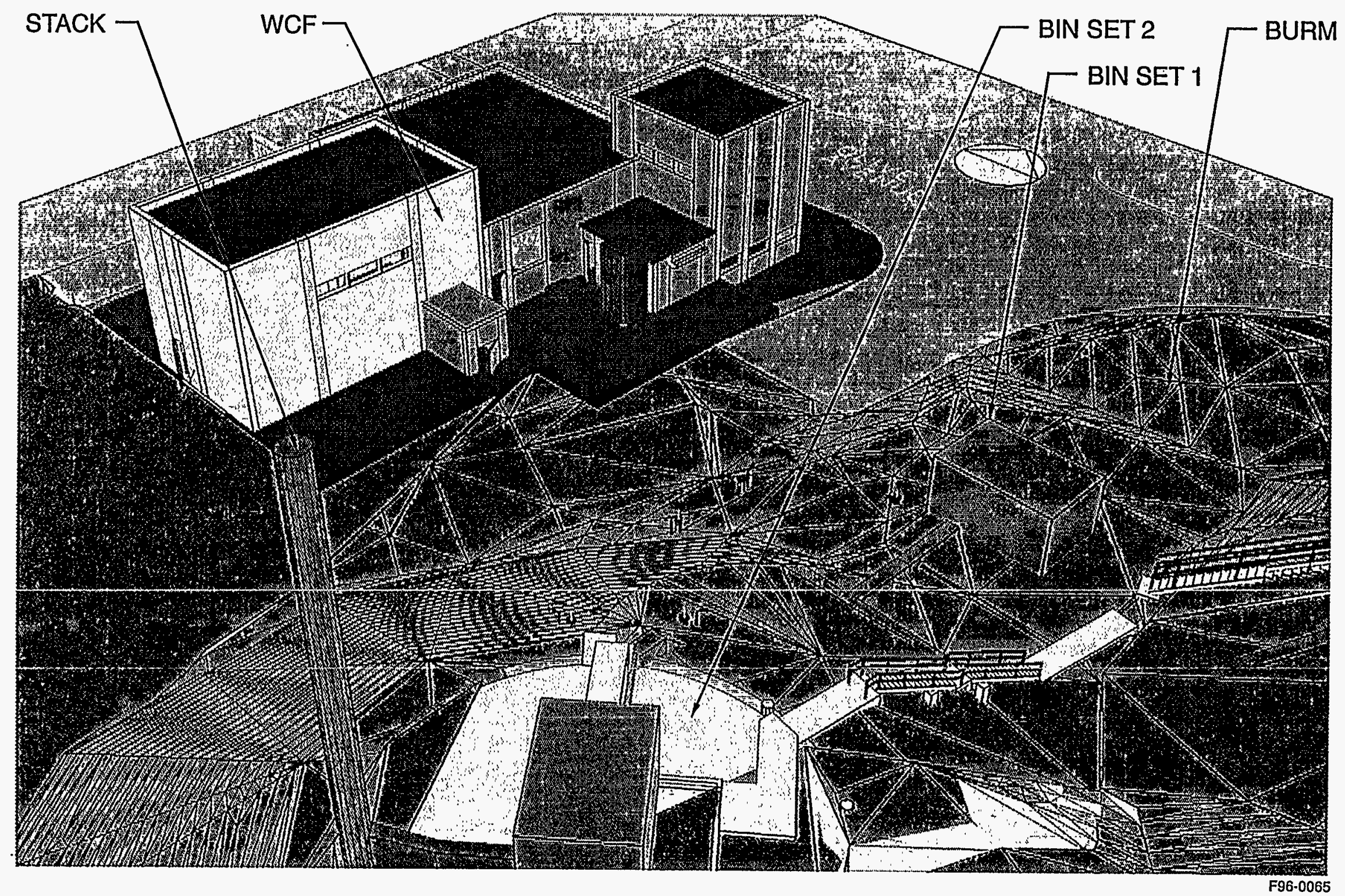

Figure 4. WCF-AS IS. 


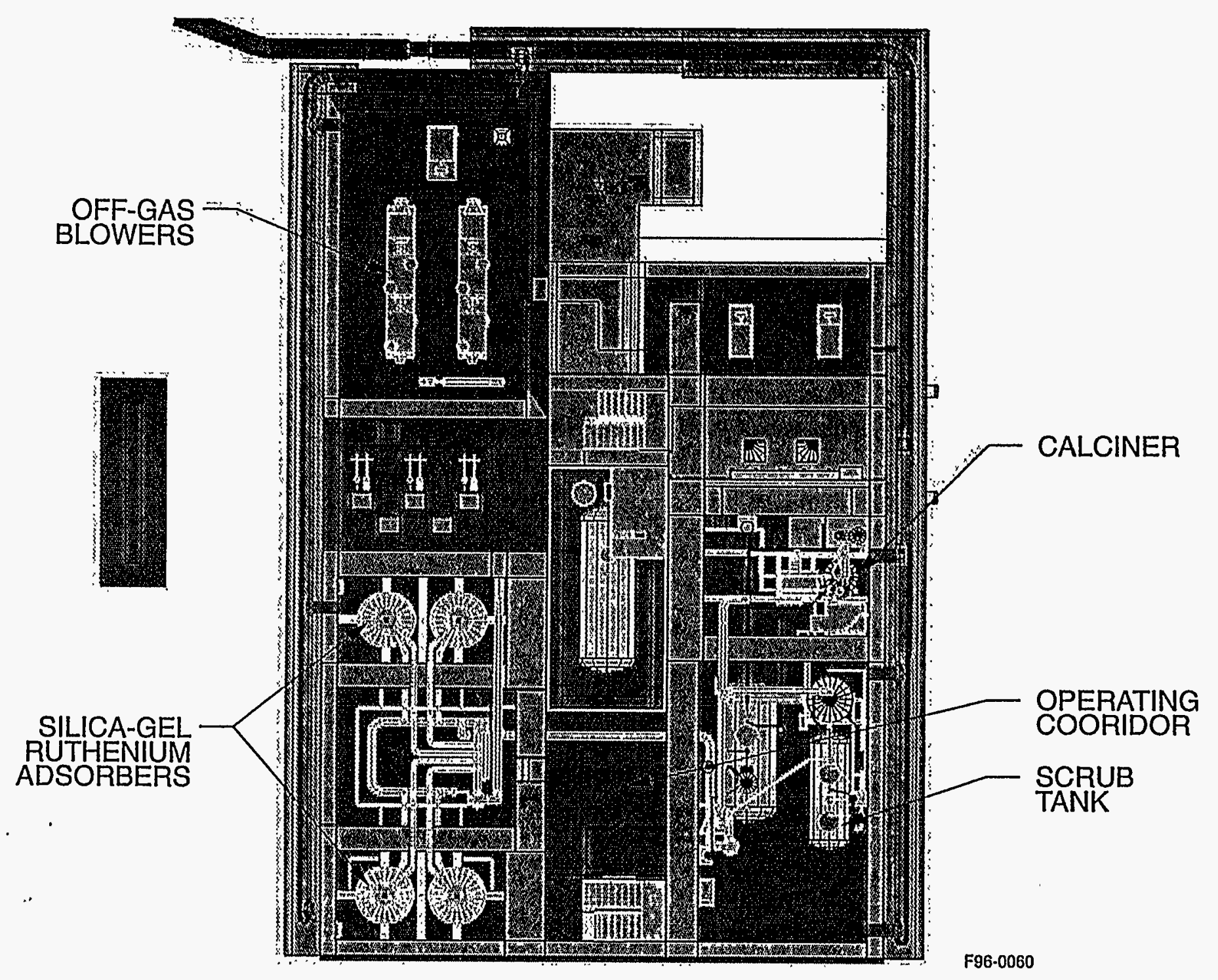

Figure 5. WCF plan. 


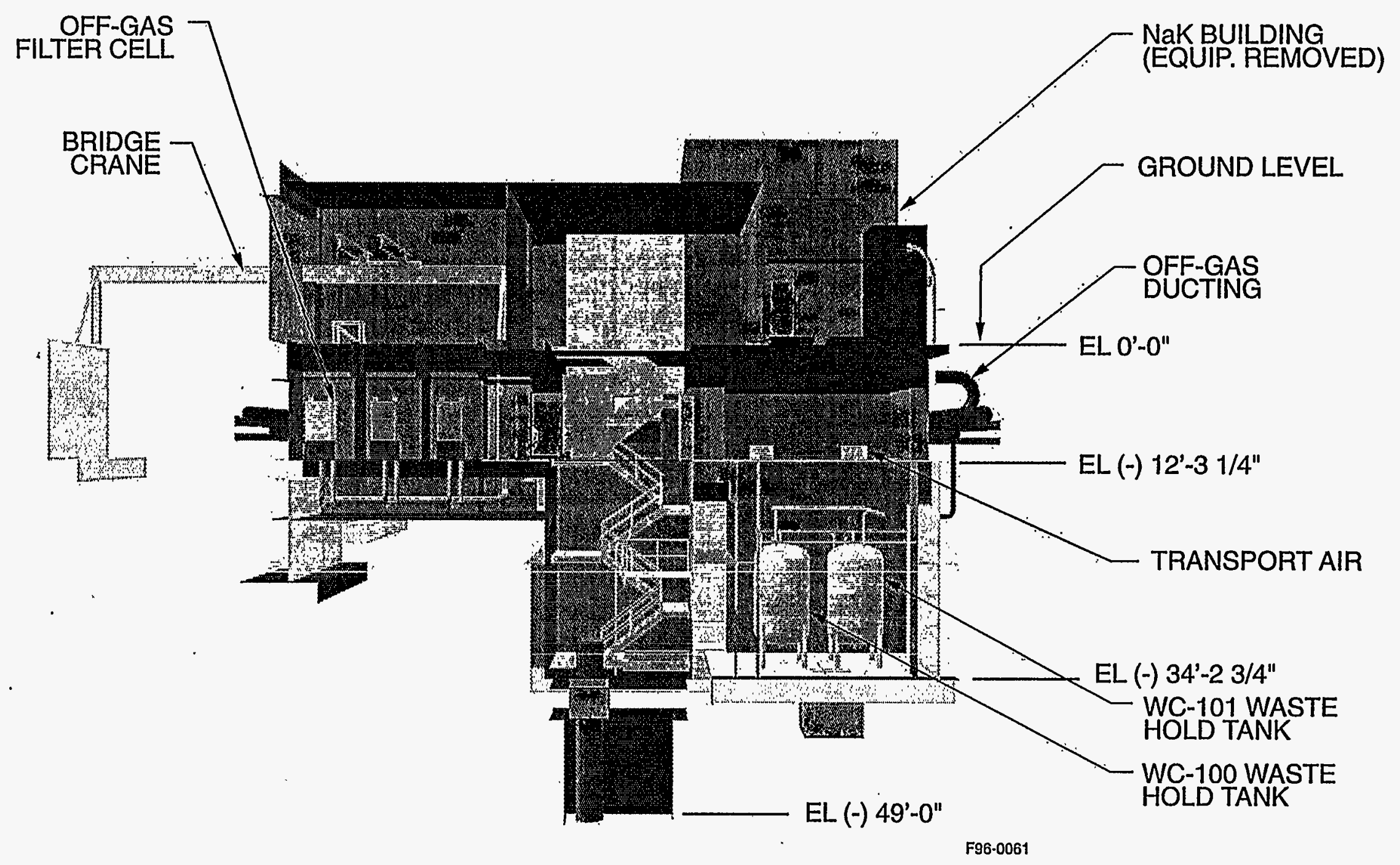

Figure 6. WCF-looking north. 
WC-118

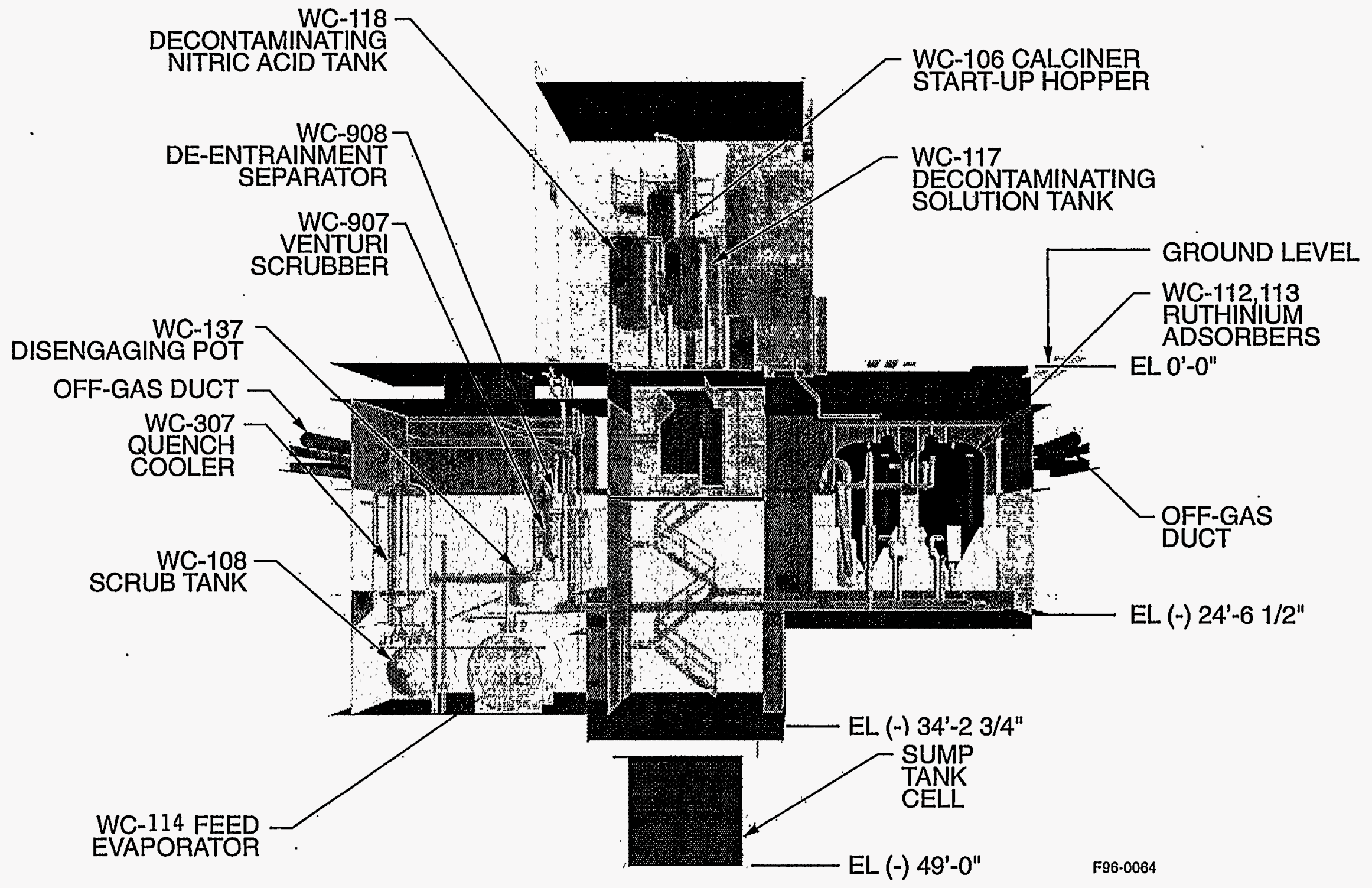

Figure 7. WCF-looking south. 


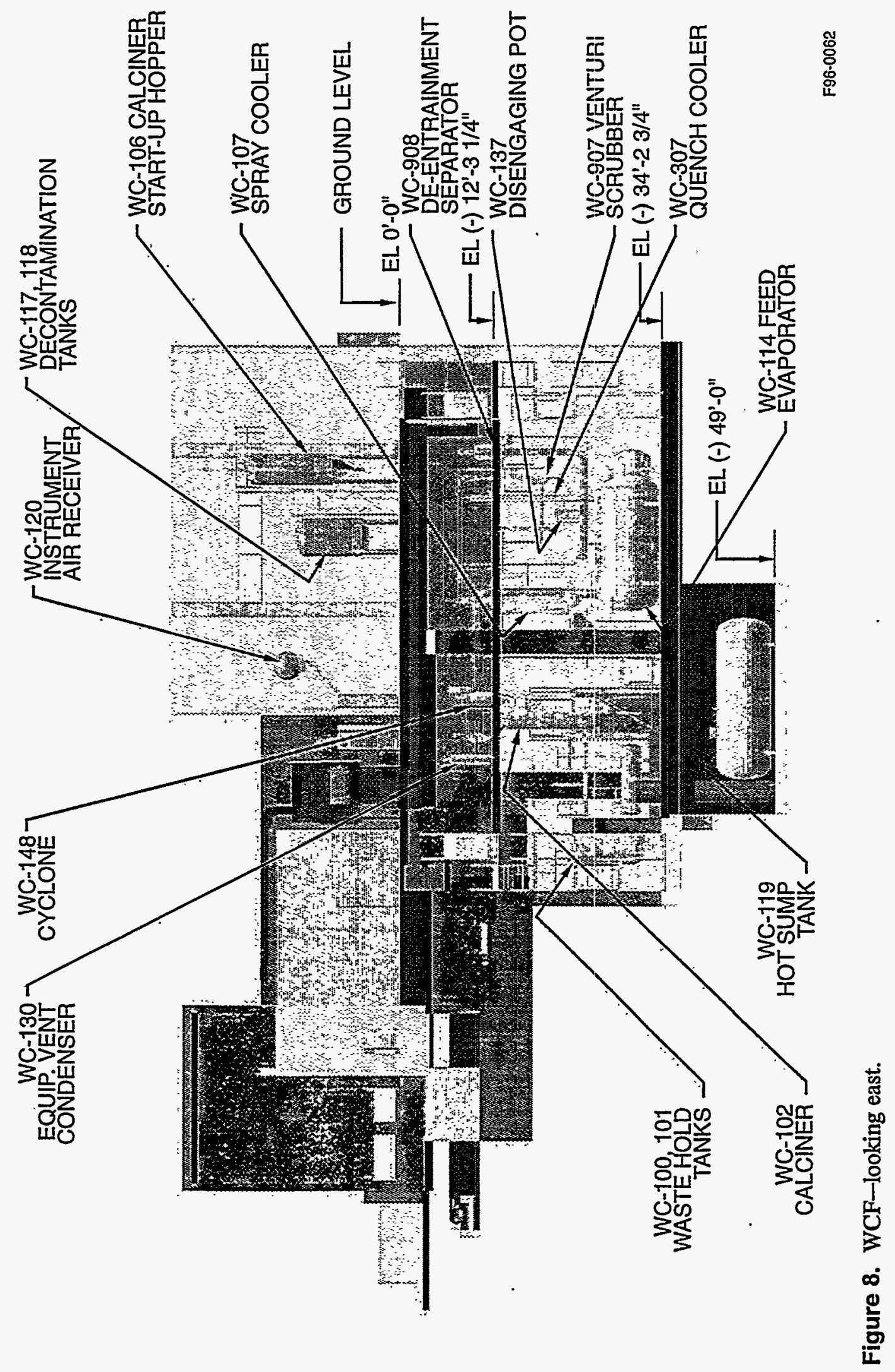




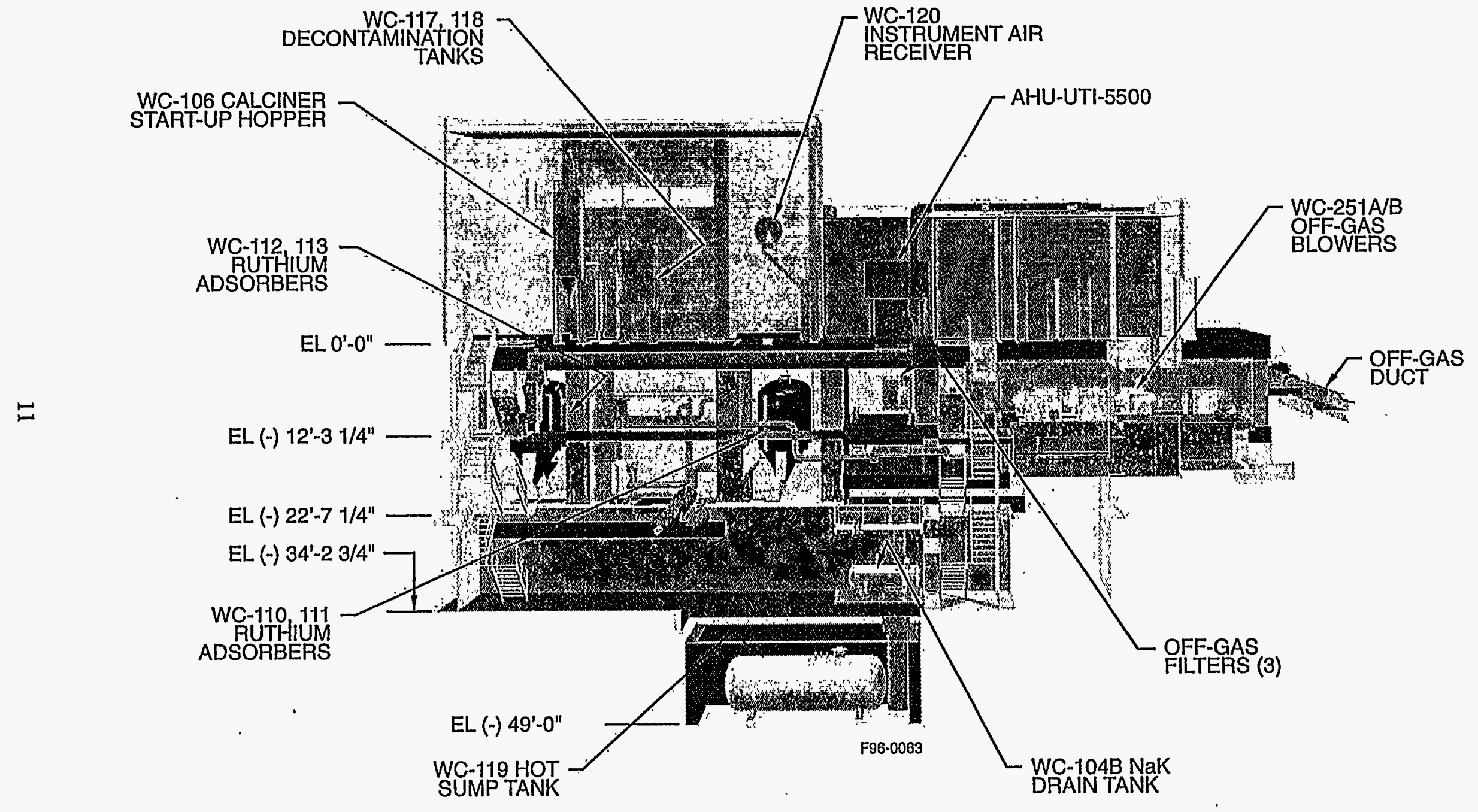

Figure 9. WCF-looking west. 


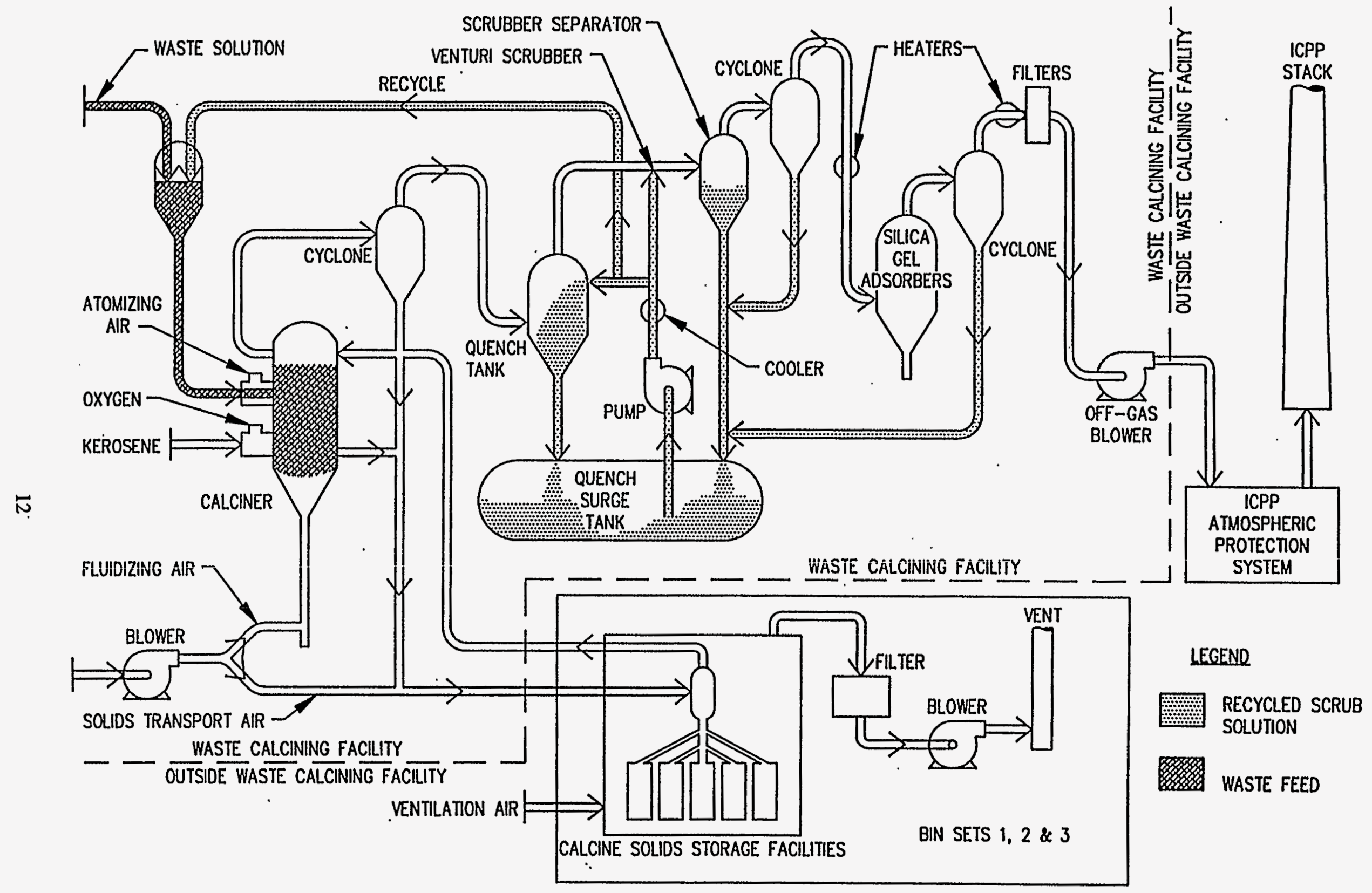

Figure 10. Schematic diagram depicting the calcining process. 


\subsection{Operating History}

Nine calcination campaigns were completed at the WCF, beginning in 1963 and ending in 1981, when the WCF was replaced by the NWCF. The calcining process involved using high-temperature to evaporate and oxidize the liquid high-level waste in a fluidized bed. Liquid waste was transferred from the ICPP tank farm to the WCF through underground pipelines. The liquid waste, which consisted of metals and nitrates in an aqueous solution, was injected into the calciner vessel, where it was heated. The original heat source was indirectly supplied by liquid sodium; a conversion was later made to in-bed combustion of kerosene and oxygen. As the water evaporated, nitrates were converted to nitrogen oxides $\left(\mathrm{NO}_{x}\right)$ and water and the dissolved metals formed oxides and salts at $500^{\circ} \mathrm{C}\left(932^{\circ} \mathrm{F}\right)$. The calcined solids were then pneumatically transferred through underground pipelines to binsets in the Calcined Solid Storage Facility (CSSF), Binsets 1, 2 , and 3 .

Process off-gases, $\mathrm{NO}_{\mathrm{x}}$ and water vapor, were quenched (cooled) using a nitric acid solution. Depleted quench solution was processed as calciner feed solution or transferred to the tank farm for storage. The cooled off-gas was passed through silica-gel adsorbers to capture radioactive ruthenium, a volatile contaminant. The off-gas also passed through a bank of HEPA filters before being discharged to the ICPP Atmospheric Protection System (APS). The APS has continued to maintain negative pressure on the WCF system since 1981 .

\subsection{Decontamination Efforts}

When the WCF calciner stopped operations in 1981, the system was emptied and the calciner and offgas cells cleaned. A review of the WCF Operations Log Book indicates that when the final calcining campaign was completed on March 16, 1981, the remaining calcined product was transferred to the CSSF for storage pending further treatment for final disposition in a geological repository. The fluidized bed was removed from the calciner and the process and transfer lines were "dusted" out with high pressure, high volume compressed air on March 20, 1981. The cells containing the process vessels were flushed down with fire hoses through the cell hatches on March 23, 1981, to remove waste residues that may have leaked from process line valves in the cells. The calciner vessel was later flushed with water on December 17, 1984, and the wash water transferred to PEW for treatment. When the WCF evaporator system was placed on standby in 1987, the tanks were drained and the waste transferred to PEW for treatment. The steam condensate and rainwater are collected in vessel WC-119 and transferred to the PEW approximately every 1 to 3 months depending on the time of year.

The out of cell operating areas were not decontaminated at the time the facility was shut down. Since 1993, a concerted effort has been made to decontaminate (chemical, radioactive, and asbestos removal) the access areas (above ground rooms and operating corridors) of WCF. The cell floors were visually examined using remote inspection video cameras in 1993 and 1994. The comprehensive inspection did not reveal the accumulation of calcine in the cells.

\subsection{Regulatory Status}

The WCF is an interim status waste management unit included in the INEL HWMA Part A Permit Application and is subject to the requirements of Idaho Administrative Procedures Act (IDAPA) 
16.01.05.009, "Interim Status Standards for Owners and Operators of Hazardous Waste Treatment, Storage, and Disposal Facilities," 16.01.05.009 (40 CFR 265 Subpart J): "Tanks," and IDAPA

16.01.05.009 (40 CFR 265 Subpart L): "Waste Piles." The tank systems in the WCF do not comply with all requirements for secondary containment in IDAPA 16.01.05.009 (40 CFR 265 Subpart J) and thus requiring the preparation and submission of a closure and post closure plan. The Operating Permits Bureau stated in their letter dated March 27, 1995, that if all contaminated system components, structures and equipment can not be decontaminated, then the tank systems must be closed in accordance with the closure and post-closure requirements that apply to landfills, IDAPA 16.01.05.009 (40 CFR 265 Subpart N). IDAPA 16.01.05.009 (40 CFR 265 Subpart J) requires that tank units be closed in accordance with the closure and post-closure requirements that apply to landfills if the operator cannot practicably remove or decontaminate the soils. IDAPA 16.01.05.009 (40 CFR 265 Subpart L) regulations for waste piles also require preparation of closure and post-closure plans if the operator cannot remove or decontaminate the subsoils.

Since it is not practical to remove the process residues, decontaminated the equipment, and remove the HEPA filters in the waste pile, the WCF will be closed in accordance with the closure and post closure requirement that apply to landfills. However, the potential for migration of hazardous waste from process residues in tanks, cells, and the waste pile is low because they are completely contained within the WCF (Building CPP-633) and will be covered with a concrete cap. The potential for a post closure release from the WCF as a capped landfill is addressed in the post closure care plan (risk assessment, cap design and groundwater monitoring).

The closure cap has been designed to minimized the exposure of workers and the public to residual hazardous and radiological constituents that will remain in place. The risk assessment summarized in the Closure Plan was performed using guidance documents prepared by the U.S. Environmental Protection Agency (EPA). These guidance documents are the Risk Assessment Guidance for Superfund Volume 1, Human Health Evaluation Manual (Part A) (EPA 1991), and "supplemental Guidance for Superfund Risk Assessments in Region 10" (EPA 1991). The two standard default exposure scenarios (i.e., current occupational and 30-year future residential) were evaluated in this risk assessment. However, several exposure pathways (i.e., soil ingestion, fugitive dust inhalation, and food crop ingestion) were eliminated because of the presence of the concrete cap. These exposure pathways were eliminated because the concrete cap is a protective barrier between the receptors on the surface of the WCF and that no crops can be cultivated in concrete. Therefore, only two exposure pathways (i.e., groundwater ingestion and external) are viable for the default for radionuclides are viable scenarios at the WCF, and the groundwater ingestion exposure pathway for the HWMA constituents (i.e., metals) remaining at the WCF.

\section{Related Issues-CERCLA}

The ICPP area includes CERCLA release sites and HWMA interim status and permitted units and in many cases a HWMA Unit sits within or over a release site. Typically a HWMA Unit is bound by the building and waste piping to and from the building. The soil around and under the HWMA unit is covered by agreement in the Federal Facility Agreement/Consent Order (FFA/CO) by CERCLA as related to past releases of contaminants. The release sites at the ICPP are grouped together and managed as Waste Area Group (WAG) 3. Therefore, when the HWMA units are closed, to landfill closure standards, the comprehensive RI/FS for the ICPP would consider any residual risk that may exist for a release from the closed WCF and at release sites outside of the WCF. The WCF is located within the CERCLA WAG 3 and has four release sites associated with the footprint of the cap. These release sites are CPP-36, $-48,-85$, and 
-91 are indicated on Figure 11 and are part of the remedial investigation at the ICPP. The the Record of Decision (ROD) for the Operable Unit (OU) 3-13, WAG 3 Comprehensive RIFS will address the remedial actions required for these release sites. The WCF closure and post-closure activities are not expected to preclude the selection of remedial actions for the CERCLA release sites in close proximity to the WCF.

However, the design features of the HWMA cap must be considered by OU 3-13 in the evaluation of remedial actions.

Supporting the cap or repairing damage to the cap must be considered when evaluating future source control or removal response actions that include excavation at site CPP-36 and CPP-91.

If an immediate soil removal action is required, it would be conducted under the FFA/CO as described in the INEL Consent Order.

\subsection{Hydrology of the ICPP}

The Big Lost River, located approximately 0.18 kilometers $(\mathrm{km})(0.1 \mathrm{mi})$ from the northwest corner of the ICPP, is the main surface water feature at the INEL. Stream flows are often depleted before reaching the INEL by irrigation diversions and infiltration losses along the river. When flow in the Big Lost River actually reaches the INEL, it is either diverted at the INEL Diversion Dam or flows northward across the INEL in a shallow, gravel-filled channel to its terminus at the Lost River sink where its flow is lost to evaporation and infiltration.

The Snake River Plain aquifer is the main body of groundwater underlying the INEL. The depth to the Snake River Plain aquifer varies from $61 \mathrm{~m}(200 \mathrm{ft})$ in the northeast corner of the INEL to $270 \mathrm{~m}(900 \mathrm{ft})$ in the southeast corner. The depth to the aquifer at the ICPP is approximately $139 \mathrm{~m}$ (455 ft). Groundwater in the aquifer flows generally to the southwest, although locally, the direction of flow is influenced by recharge from rivers, surface water spreading areas, and heterogeneities in the aquifer. At the ICPP, groundwater flow is generally from north-northeast to south-southwest. Tracer studies at the INEL indicate natural flow rates range from 5 to $20 \mathrm{ft}$ per day (EG\&G 1985). Discharges of approximately $8.7 \times 10^{6}$ acre-feet (ac-ft) occur annually through springs in the Hagerman area and upstream from American Falls Reservoir and through irrigation well withdrawals (EG\&G 1985).

Perched water bodies originate beneath the Eastern Snake River Plain in areas where sufficient quantities of water move downward and sedimentary layers impede further infiltration. Several perched water zones have been identified at the ICPP with the upper and a lower zones having been investigated and sampled. An upper perched water zone is located approximately $34 \mathrm{~m}(110 \mathrm{ft})$ below land surface, at the contact between surficial alluvium and the uppermost basalt layer. The lower perched zone is located in a sedimentary layer about $115 \mathrm{~m}(380 \mathrm{ft})$ deep. 


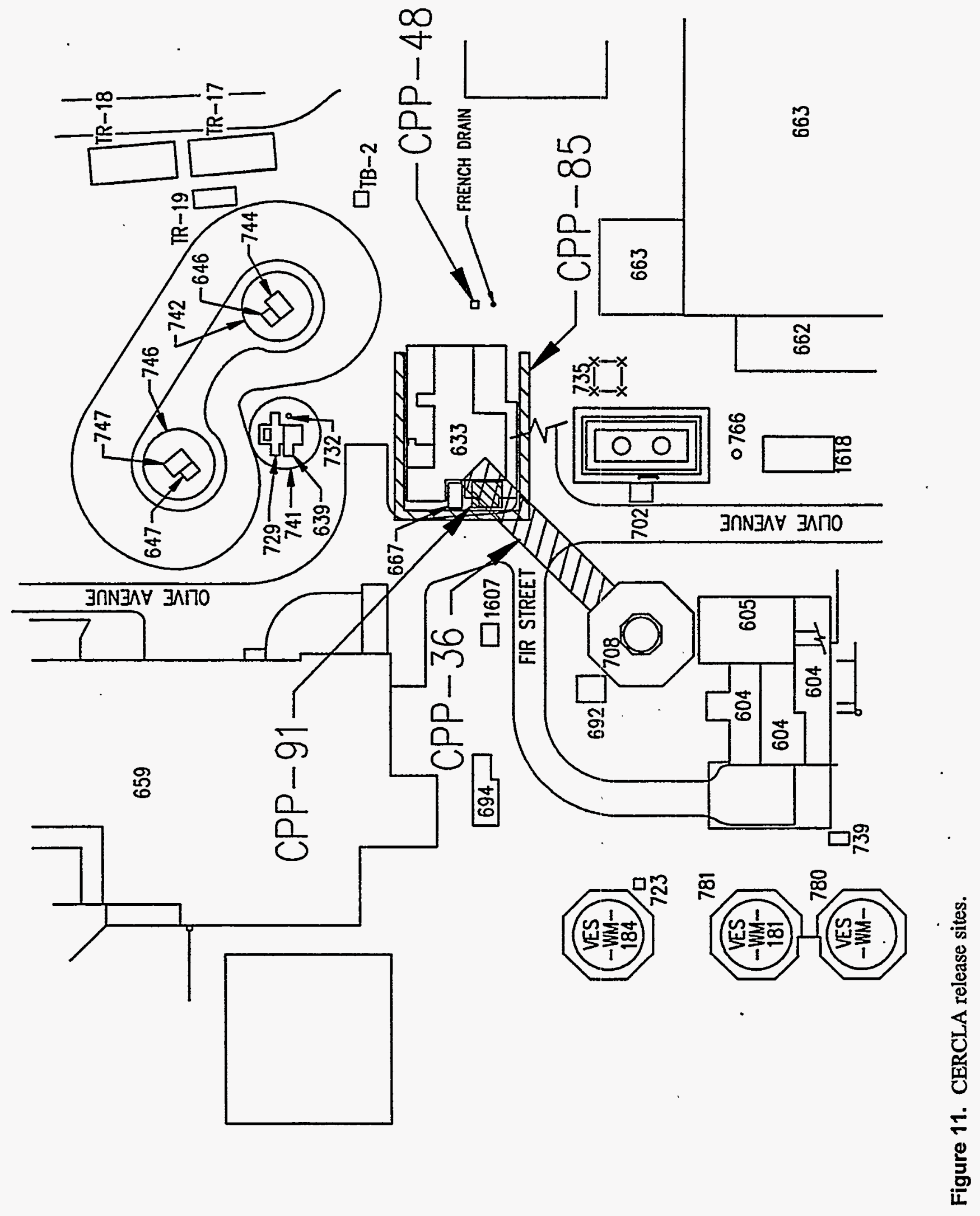


Closure activities planned for the WCF such as grouting the building in place, permanently blocking all piping (i.e., capping, grouting, or removal) exiting the building, and placement of a final cover over the grouted structure will reduce the potential for contaminant migration from the WCF and be protective of the groundwater. A water balance for the WCF indicates minimal infiltration rates due to low precipitation rates, high evapotranspiration rates, and controlled runoff at the site. Characteristics of the unsaturated and saturated zones such as presence of interbeds with lower permeability and higher adsorptive capacity than the basalt, and depth to groundwater $142 \mathrm{~m}$ (464 ft measured in WM-18 near the WCF) all indicate closure of the WCF will not result in adverse impacts to the groundwater. 


\section{WASTE INVENTORY}

\subsection{Characteristics of Processing Residues}

The high-level mixed waste and the low-level mixed waste (sodium) historically processed through the WCF had the following characteristic waste codes D002 (corrosive), D007 (chromium), D008 (lead), D009 (mercury), D011 (silver), and the listed waste codes as identified in the Listed Waste Determination Report (see Table I). The chemicals listed in Table I are unused or off-specification commercial chemical products and decontamination solutions that were identified in an inventory of ICPP facilities and laboratories as having been discarded to the ICPP Waste System. The additional waste codes identified in the Part A of the INEL HWMA Permit were a conservative filing to cover chemicals that may have been used and to allow the future use of the WCF evaporator with waste that might contain these additional constituents. The WCF evaporator has not been used to treat waste containing these additional waste codes. The waste codes listed in the Listed Waste Determination report have been concluded to have entered the ICPP waste stream and have been applied to all mixed wastes treated in the WCF.

The majority of the listed waste codes identified in Table 1 and associated with the WCF are from past practice of transferring off-specification or unused commercial chemical products (reagents) from laboratories and decontamination process solutions to the Process Equipment Waste (PEW) evaporator and tank farm. These chemicals were primarily used by the laboratory for process control analyses and were not discarded in large quantities.

These chemicals were dispersed from 1963 until 1988 in the 28.4 million liters (7.5 million gallons) of waste; 15.2 million liters ( 4 million gallons) processed through the WCF; 5.6 million liters ( 1.5 million gallons) processed through the NWCF; and 7.6 million liters ( 2 million gallons) still in storage in the tank farm. Liquid laboratory waste and decontamination wastes were transferred to the PEW evaporator to remove part of the water prior to storage in the tank farm. The strong nitric acid solutions and elevated temperatures in the PEW evaporator would have digested the majority of the organics, cyanides, and sulfides. The remaining metal compounds would have been converted to nitrates and become indistinguishable from the other metal constituents from reprocessing. The temperature of the waste during storage in the tank farm also would promote the evaporation of the volatile constituents. Organics compound remaining in the waste would have been destroyed during calcination.

All WCF vessels except WC-119 have been emptied and ventilated since 1987 and are dry. Vessel WC-119, the bottoms tank, collects rainwater leaking through the roof and steam condensate from the heating system. The calciner and off-gas cells were flushed with water and the resulting solution was transferred to PEW. Based on the above discussion it is not expected to find detectable concentration of these organic constituents in the process residues found in vessels and piping, or on the cell floors. Consequently, any remaining residue of these chemicals would present no significant threat to human health or the environment.

Table 1 follows and identifies the listed wastes and concentrations that have been determined to have entered the tank farm and were treated in the WCF processes. These listed waste codes have been assigned to process residues since they are derived from waste that had these waste codes. 
Table 1. Listed wastes determined to have been used at ICPP.

\begin{tabular}{|c|c|c|}
\hline Constituent & Waste code & Total volume $(\mathrm{kg})$ \\
\hline Acetonitrile & U0030 & .280 \\
\hline Ammonium vanadate & P119 & 0.000096 \\
\hline Carbon disulfide & F005 & 2.33/F-List \\
\hline Formaldehyde & U122 & 0.0252 \\
\hline Formic acid & U123 & 1.42 \\
\hline Hydrazine & U133 & 0.401 \\
\hline Hydrogen fluoride & U134 & 170.5 \\
\hline 2-nitropropane & F005 and U171 & $0^{2}$ \\
\hline Sodium azide & 105 & 0.600 \\
\hline Thiourea & U219 & 12.39 \\
\hline Vanadium oxide & P120 & 4.8 \\
\hline Aniline & U012 & 4.74 \\
\hline Benzene & U019 and F005 & 58 and F-List \\
\hline Bromoform & U225 & $0^{*}$ \\
\hline Carbon tetrachloride & $\mathrm{U} 211$ and $\mathrm{F} 002$ & 16 U-List and $240 \mathrm{~F}$-List \\
\hline Chloroform & U044 & 1.8 \\
\hline 1,4-dioxane & $\mathrm{U} 108$ & 22 \\
\hline Isobutyl alcohol & $\mathrm{U} 140$ and F005 & $0^{2}$ \\
\hline Lead acetate & U144 & $0^{2}$ \\
\hline Mercury & $\mathrm{U} 151$ & $0^{2}$ \\
\hline Methylene chloride & $\mathrm{U} 080$ and $\mathrm{F002}$ & 0.260 F-List \\
\hline Methyl ethyl ketone & U159 and F005 & $1 \mathrm{~F}-$ List \\
\hline Methyl iodide & U138 & $0^{2}$ \\
\hline Phenol & U188 & 0.998 \\
\hline Potassium cyanide & P098 & 0.000032 \\
\hline Pyridine & U196 and F005 & 84.9 \\
\hline Selenium dioxide & U204 & 0.038 \\
\hline Silver cyanide & $\mathrm{P} 104$ & 0.760 \\
\hline Sodium cyanide & P106 & $0^{2}$ \\
\hline Tetrachloroethylene & $\mathrm{U} 210$ and $\mathrm{F} 002$ & $0^{2}$ \\
\hline Toluene & $\mathrm{U} 220$ and $\mathrm{F} 005$ & 18 F-List \\
\hline 1,1,1-trichloroethane & $\mathrm{U} 226$, and $\mathrm{F} 002$ & 10900 F-List \\
\hline 1,1,2-trichloroethane & $\mathrm{U} 227$ and F002 & 10900 F-List \\
\hline Trichloroethylene & $\mathrm{U} 228$, and $\mathrm{FOO} 2$ & $0^{2}$ \\
\hline
\end{tabular}




\subsection{Quantities of Process Residues}

An investigation was conducted in 1995 to estimate the quantity of process residues that will remain in the WCF at closure. Since, the radiation fields are too high to allow safe entry for visual inspections or hands-on measurements of the residues in the cells and vessels, a conservative engineering estimate has been made. This conservative estimate is based on a review of the operating records, design specifications, drawings, and safety analysis reports. The investigation reported an estimated quantity of process residue in WCF vessels, piping, and cell of $0.39 \mathrm{~m}^{3}\left(0.51 \mathrm{yd}^{3}\right)$ (Diemer and Archibald 1995).

A summary of the assumptions and findings are presented in the following sections.

\subsubsection{Evaporator and Associated Tanks}

The evaporator system vessels were assumed to have a $25.4 \mathrm{~mm}$ (1-in.) layer of dry sludge on the bottom and due to rinsing $5 \%$ of the original contaminants are still present in this layer. Estimated quantity of process residue in this system is $0.0005 \mathrm{~m}^{3}\left(0.0007 \mathrm{yd}^{3}\right)$.

\subsubsection{HEPA Filters}

Four of the five HEPA filters in the waste pile were used during the last calcining run and are each estimated to contain $3 \mathrm{~kg}$ (6.61 lb.) of residue. This estimate is based on a 1992 NWCF HEPA filter investigation. The fifth filter was not used during calciner operation and would only contain radioactive constituents. The estimated quantity of process residue on the filters is $0.015 \mathrm{~m}^{3}\left(0.018 \mathrm{yd}^{3}\right)$.

The filters on line now were installed after calciner operations were concluded. These filters would only contain radioactive constituents.

\subsubsection{Calciner and Piping}

The calciner system vessels, equipment, and piping are conservatively estimated to have a $0.35 \mathrm{~mm}$ ( 0.014 in.) layer of process residue coating all internal surfaces. This assumption is based on a typical particle of process residue having an average size of $0.35 \mathrm{~mm}(0.014 \mathrm{in}$.) and would remain on the internal surfaces after the waste has been removed from the equipment. For the $10.67 \mathrm{~m}(35 \mathrm{ft})$ of process piping around the calciner and the first 20-feet of off-gas piping it was assumed to contain $38.1 \mathrm{~mm}(1.5 \mathrm{in}$.) and $25.4 \mathrm{~mm}$ ( $1 \mathrm{in}$.) of process residues on the bottom of the pipes, respectively. The estimated quantity of process residues in this system is $0.15 \mathrm{~m}^{3}\left(0.18 \mathrm{yd}^{3}\right)$.

\subsubsection{Off-Gas System}

The pressure drop across the ruthenium adsorbers when the calciner operations were stopped indicated that the adsorbers were at the design pressure drop limit of $356 \mathrm{~mm}$ (14 in.) of water. Based on the pressure drop across the adsorbers, it is estimated that the quantity of process residues in the four adsorbers is 0.070 $\mathrm{m}^{3}\left(0.092 \mathrm{yd}^{3}\right)$. 


\subsubsection{Cell Floors}

The cell floors (except absorber cell) were examined using remote inspection videos made in 1993 and 1994. These inspections show that there is an accumulation of dust and debris in the cells, but no accumulation of calcine. Therefore, it was conservatively assumed that the cells were contaminated with a $0.35 \mathrm{~mm}(0.014 \mathrm{in}$.) layer of process residues. Process residues were adjusted for the following cells based on: (1) higher than average radiation fields in the sample blister and adsorber manifold, (2) lower than normal radiation fields in the hot sump and waste hold cells, and (3) documented washing of the calciner and off-gas cells. The estimated quantity of process residue on the cell floors is $0.084 \mathrm{~m}^{3}\left(0.11 \mathrm{yd}^{3}\right)$.

\subsubsection{Product Transfer Piping and Off-Gas Ducts}

The product transfer piping was assumed to have the internal surfaces coated with $0.35 \mathrm{~mm}, 10.67 \mathrm{~m}$ ( $35 \mathrm{ft}$ ) of piping near the calciner had $38.1 \mathrm{~mm}$ (1.5 in.) layer on the bottom, and that 11 valves were plugged with process residues. $10.67 \mathrm{~m}$ ( $35 \mathrm{ft}$ ) of off-gas duct contained $25.4 \mathrm{~mm}(1 \mathrm{in}$.) of process residue on the bottom. The estimated quantity, of process reside, in calciner transfer piping, valves, and ducts is $0.084 \mathrm{~m}^{3}$ $\left(0.11 \mathrm{yd}^{3}\right)$.

\subsection{Lead Shielding, Instruments Containing Mercury, and Equipment Oil}

An engineering evaluation of other hazardous material that will remain in the WCF has been conducted by reviewing design drawing, equipment specifications, comparison to the NWCF, and personal knowledge of the WCF operation personnel. Based on this review, approximately, 15.24 metric tons (15 tons) of lead shielding is found structurally in the cell walls, lining pipe corridors and sample blister and filling doorways will be left in place. The quantity of mercury contained in the in-cell instruments is conservatively estimated to be $11.8 \mathrm{~kg}$ ( $26 \mathrm{lbs}$ ). The quantity of oil contained in the in-cell equipment blowers and observation windows is estimated to be 75.7 and 1,022 liters (20 and 270 gallons), respectively. The blowers contain 40 wt. lubrication oil and the observation window contain mineral oil. Due to the radiation fields and radioactive contamination, the WCF will be closed with these constituents in place. 


\section{CLOSURE ACTIVITIES}

This section is divided in to two parts, Section 4.1 discusses the activities necessary to prepare the WCF for closure and Section 4.2 discusses the closure activities necessary for physical closure of the WCF.

Closure activities in the WCF consists of waste pipe plugging, cell and vessel grouting, and construction of the concrete cap cover over the footprint of the WCF. The WCF will be considered physically closed when these activities have been completed and certified by an independent professional engineer

Closure activities will be considered complete upon submittal of Certification of Closure by an independent qualified Idaho registered professional engineer, LITCO, and the DOE-ID to the Director of the Idaho Department of Health and Welfare (IDHW). Certification of Closure will verify that the WCF unit has been closed in accordance with the specifications of the approved closure plan. Copies of the documentation supporting the independent registered professional engineer's certification will remain at the ICPP in the event that this information is requested by the Director of the Idaho Department of Health and Welfare.

WCF Closure Comprehensive Work Plan, 1996, is summarized in the following sections and includes activities necessary to prepare the WCF for closure as well as the activities needed to close the facility.

\subsection{Activities Necessary to Prepare the WCF for Closure}

\subsubsection{Reroute Utilities}

The utilities to the WCF are associated with other buildings and systems. The utilities will be rerouted to provide continued service to these other building and systems. The WCF will be isolated from plant utilities and temporary service will be provided as required for closure activities, Isolating the WCF from the plant utilities will eliminate sources of water or steam under the cap.

\subsubsection{Above Grade Equipment Dismantlement and Grouting}

The tanks and piping in the chemical make up room will be dismantled. Equipment that can be reused will be excessed. Equipment that can't be reused will be sized, placed on the ground floor and grouted in place with the superstructure. This equipment does not contain hazardous or radioactive contaminants. Equipment in other parts of the ground floor are contaminated with radioactive constituents and will be dismantled and grouted at grade along with the WCF superstructure (see Section 4.3).

\subsubsection{External Utility Pipe Capping}

Utility lines will be cut and capped inside and outside of the WCF. Utility and non-waste piping will be capped or plugged to prevent water from entering the WCF. 


\subsection{Closure Activities for WCF}

\subsubsection{Grouting (Void Filling)}

The cells and operating corridors will be filled with grout to prevent the potential for subsidence of the cap in the future. Vessels will be grouted to reduce the open voids within the grouted cells. Grouting was selected because it is pumpable, self-leveling, and the capability to be formulated in a variety of compositions depending the application, which fits the needs better than sand. The pipes encountered during closure, penetrating the external walls of the WCF will be filled with grout and/or capped to prevent moisture from entering the WCF. Figure 12 shows the proposed grouting sequence for the vessels and cells.

4.2.1.1 Capping of the Waste Piping. Waste piping penetrating the exterior walls of the WCF will be flushed by pumping grout through the pipe into tanks in the WCF and capping. Waste piping will be grouted and capped from the nearest valve box outside the WCF, back into the WCF. The off-gas duct (CERCLA release site CPP-85) is approximately 2 to $3 \mathrm{~m}(6.6$ to $9.8 \mathrm{ft}$ ) below ground level and runs around three sides of the perimeter of the WCF. The duct is constructed of clay pipe and encased in a concrete shield. The off-gas duct will be filled during the grouting of the cells. The product transfer and return air lines are enclosed in a steel duct surrounded by a concrete encasement. The steel duct will be grouted by pumping grout through holes bored through the encasement and into the steel duct. The product transfer and return air lines will be flushed with grout and then grouted full from a decontamination drop located between the WCF and the Binset 1 [approximately $23 \mathrm{~m}$ (75 ft) east of WCF], back into the WCF.

4.2.1.2 Vessel Grouting. Vessels will be grouted to reduce the open voids within the WCF, but grouting is not required for the structural support of the cap. Therefore, the major vessels ( $>55$ gallons) will be filled with grout as full as is practical using the existing piping in the chemical make-up area on the ground floor. If a pipe becomes plugged and there is not a back up, it may be necessary to bore a hole into the vessel form the floor above to place the grout. Vessel grouting will start with the vessel in the lowest cell and proceed upward.

4.2.1.3 Cell Grouting. Cells and operation corridors will be grouted in lifts, as depicted in Figure 12 , to allow for curing and heat dissipation. The lift thicknesses will vary depending on the cell being filled, but typically will be 0.3 to $1.3 \mathrm{~m}$ ( 1 to $4 \mathrm{ft}$ ) as indicated on Figure 12 . Grout will be pumped into cells and operating corridors through existing piping where available or through $\mathrm{K}$-plugs or drill holes bored from the ground floor. Many of the cells and operating corridors will require multiple access points to maintain a level lift when filling. The cells and operating corridors will be considered full when grout becomes visible in the upper most K-plugs or drill holes being used to fill that cell or corridor. Additionally, the cell or corridor ventilation will stop as the ceiling exhaust ventilation holes located near the top of the cells fill with grout.

NOTE 1: K-plugs are removable access plugs through the roof of the cell.

NOTE 2: The cell roofs are constructed of 3 feet of reinforced concrete.

4.2.1.4 Contamination Release Concerns. The potential of spreading contamination from . either the radioactive or hazardous constituents to the environment from pipes, vessels, or cells during the placement of grout or concrete has been evaluated and the results are presented in the following sections. 



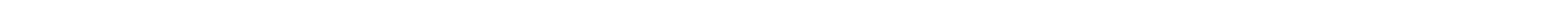




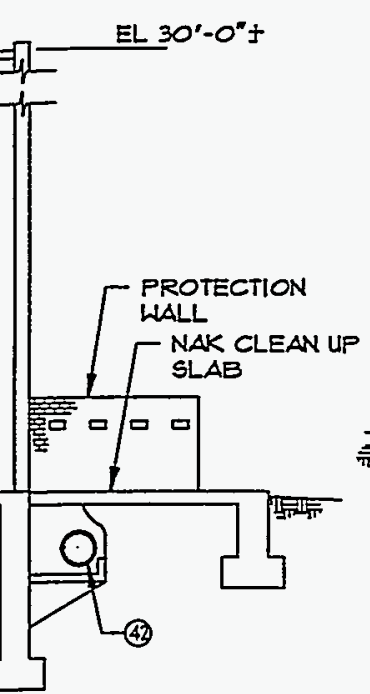

EL $2 T^{\prime}-O^{\prime \prime}+$

REV

2 
Cell Filling-The WCF substructure is constructed of heavily reinforced two-foot thick concrete walls and two-foot thick floors. The cells have stainless steel liners covering the floor with a fourinch high containment lip at the walls. The calciner cell floor and walls are totally lined with stainless steel while the blend and hold cell does not have a stainless liner. During shutdown, several of the cells containing process vessels were washed down and the flushed residues transported to the PEW system, as described in Section 2.3. Little if any free contamination is expected to be present in these areas.

The initial placement of 0.6 to $1.2 \mathrm{~m}$ ( 2 to $4 \mathrm{ft}$ ) high concrete lifts will cover and immobilize any contamination that may still be present on the stainless liner floors. Subsequent lifts will lay upon the previous lifts preventing the migration of liquids downward to the subsurface geology. Any microcracks in the walls will be quickly filled and plugged by the concrete mixture. Mockup laboratory tests have determined that $1 / 8$-inch diameter holes would plug with a thin slurry grout made up of only flyash and cement at $4.23 \mathrm{~kg} / \mathrm{cm}^{2}$ (60 psi) pressure if not filtered coming out of the delivery pump. The concrete formulation for cells consists of sand and aggregate and is much thicker than the slurry grout. This mix will certainly not permeate any cracks to the environment, rather tending to plug and fill any discontinuities and

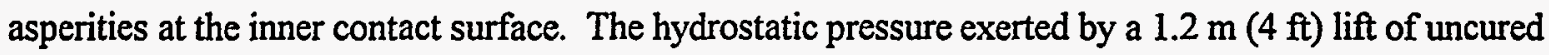
concrete is much lower than the measured $4.23 \mathrm{~kg} / \mathrm{cm}^{2}(60 \mathrm{psi})$ test condition, thus preventing the extrusion of concrete through the walls. The concrete has an initial set time of two hours whereby in the process of hydration, the cement constituents in the concrete formulation will assimilate and tie up the water in the mixture to complete the exothermic chemical reaction. Free water will not be available to transport any loose contamination to the environment.

Vessel and Pipe Filling-The facility's stainless steel drain piping is encased in concrete as it goes from different locations in the facility through soil to the sump tank. All other exterior piping entering the facility is either encased in concrete or sleeved or both.

For pipe closure, the lines will either be flushed, capped, and filled or simply filled with grout injected toward the facility with the grout scouring the interior of the piping and ending up contained in vessels in the cells with the barriers described above prior to curing and final solidification. The nature of these tasks makes it highly unlikely of a release during the grouting. If a leak were to occur, based upon mockup testing, the grout would solidify when not in motion and quickly be immobilized. Vessels have been analyzed statically to determine that the supports will maintain integrity following placement of grout, as grout. The piping has been evaluated to ensure that the delivery pressures are well within the design capacity of the specific pipes. In all cases the capacity far exceeds the expected pressure exerted by the grout.

In summary, the inherent barriers and the nature of the concrete, grout and the process of delivery of the formulations makes the potential of a release of contamination to the environment highly improbable. Measures have been taken in the design to tightly control the procedures and sequence to safely achieve the desired filling of the piping, vessels, and subsurface structures of the WCF as described in Sections 4.1 and 4.2 of this closure plan.

4.2.1.5 Description of the Superstructure Removal and Placement. The superstructure consists of the above ground portion of the WCF. The WCF above-grade walls are constructed of 12-inch concrete blocks. Following radiation surveys and hot spot stabilization with paint or adhesive fixatives, the roof and walls would be dismantled using a backhoe with a crushing and shear jaw attachment or similar equipment. The walls and roof structure would then be further sized and placed on the floor over the grouted and cured below-grade structure. Suspension of radioactive or asbestos particles would be controlled by 
application of water or other dust suppressants during the dismantling and sizing processes. Track mounted equipment, such as bulldozers, would be used to level and compact the rubble, and grout would be applied to fill empty spaces and voids in the rubble. The entire structure would then be covered by a reinforced concrete cap.

\subsubsection{Description of the Cap}

The WCF is being closed with hazardous constituents in place and will meet the closure requirements applicable to landfills by the construction of an engineered concrete cover or cap over the grouted cells, vessels, and superstructure. The landfill cover or cap requirements for design and construction are listed below. The cover or cap will:

- Provide long-term minimization of migration of liquids through the closed landfill

- Function with minimum maintenance

- Promote drainage and minimize erosion or abrasion of the cap

- Accommodate settling and subsidence so that the cover's integrity is maintained

- Have a permeability less than or equal to the permeability of any bottom liner system or natural subsoils present.

The design of the WCF concrete cap complies with the requirement identified above. The cap will be constructed of a low permeability reinforced concrete, a minimurn of $0.31 \mathrm{~m}$ ( $12 \mathrm{in}$.) thick with at least $1 \%$ slope from the center to the edges of the cap. The cap will extend about five feet past the ground level footprint of the WCF building as indicated on Figures 13 and 14. Water stops will be installed in the joints in the cap as presented on Figures 15 and 16 and the concrete will have a permeability in the order of $1 \times 10^{-12}$ $\mathrm{cm} / \mathrm{sec}\left(3.9 \times 10^{-13} \mathrm{in} . / \mathrm{sec}\right)$ (Keck 1995). The concrete will have a minimum compressive strength of 4500 psi after 28 days (WCF Closure Comprehensive Work Plan 1996). The surface soils have a permeability of 2 $\times 10^{-2}$ to $2 \times 10^{-1} \mathrm{~cm} / \mathrm{sec}\left(7.8 \times 10^{-3}\right.$ to $7.8 \times 10^{-2} \mathrm{in}$. $\left./ \mathrm{sec}\right)$ and the sedimentary interbed soils have a permeability of $1 \times 10^{-3}$ to $9 \times 10^{-5} \mathrm{~cm} / \mathrm{sec}\left(3.9 \times 10^{-4}\right.$ to $\left.3.5 \times 10^{-5} \mathrm{in} . / \mathrm{sec}\right)$ (Keck 1995).

The concrete cap will function with a minimum of maintenance, reduce erosion, and the grade of the surface will promote drainage away from the cap. The below ground voids created by the vessels and cells will be filled with a grout to prevent subsidence and maintain the integrity of the cap. Water that drains off of the cap or toward the cap will be collected and conducted away from the WCF by the storm water drains and ditches as shown on Figure 17.

\subsubsection{Inspections and Monitoring During Pre-Closure and Closure}

HWMA inspection and monitoring of the WCF will be maintained before and during closure activities. As parts of the WCF become inactive or emergency equipment is not needed the inspection and monitoring requirements for those specific areas or emergency equipment will be terminated. Inspection requirements for vessels, cells, and equipment will be terminated when grouting begins or it is removed 


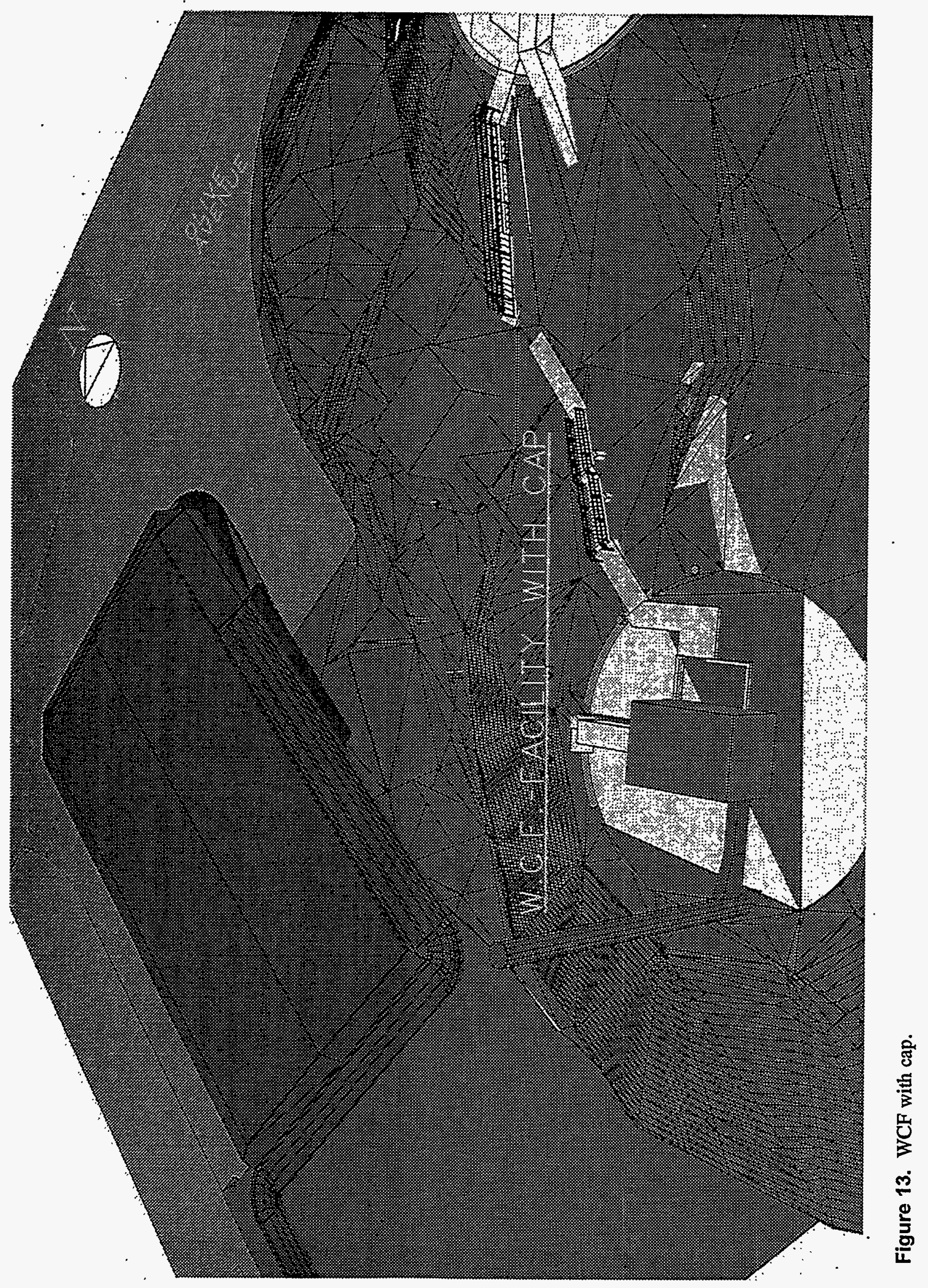




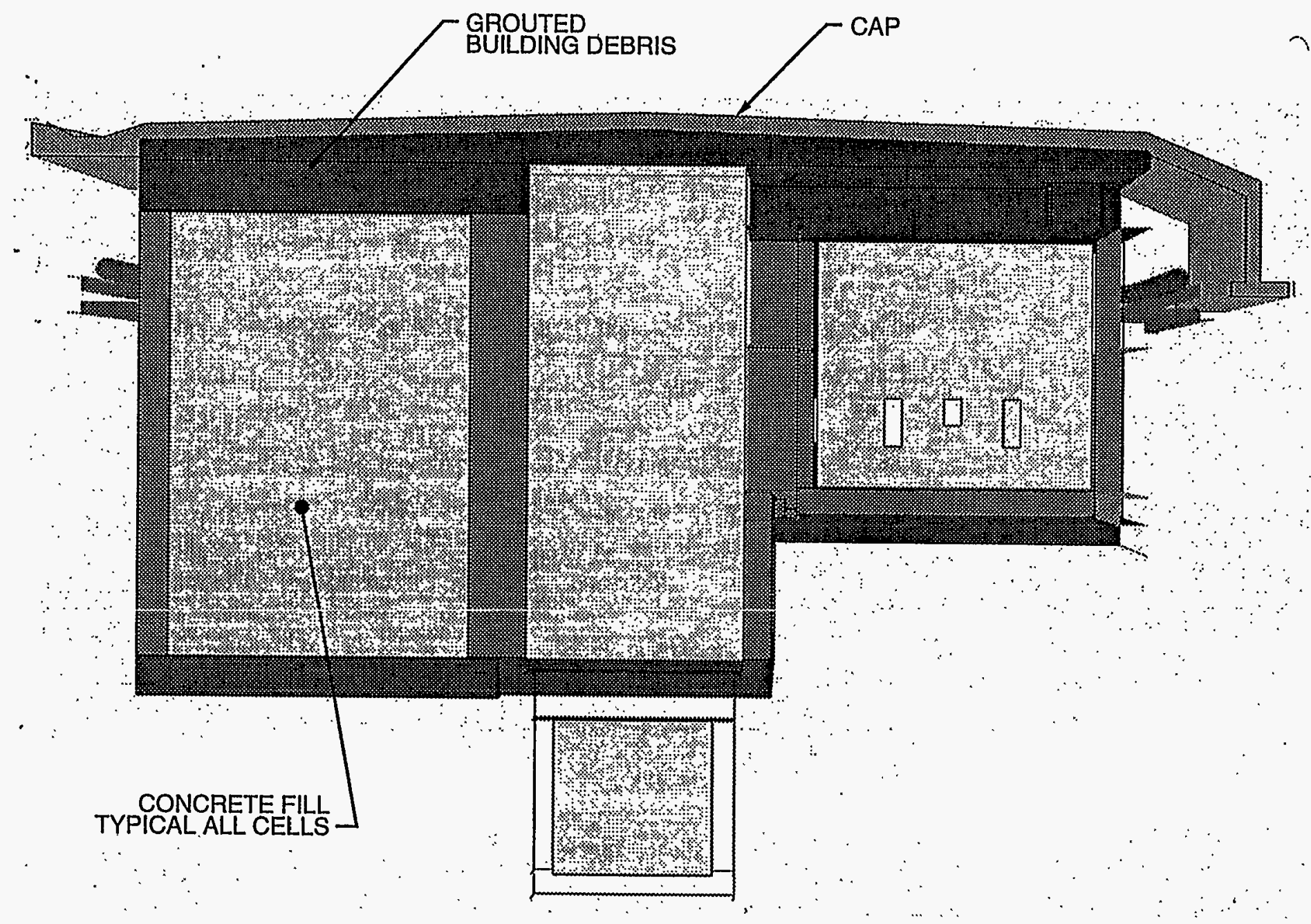

Figure 14. WCF-looking south. 


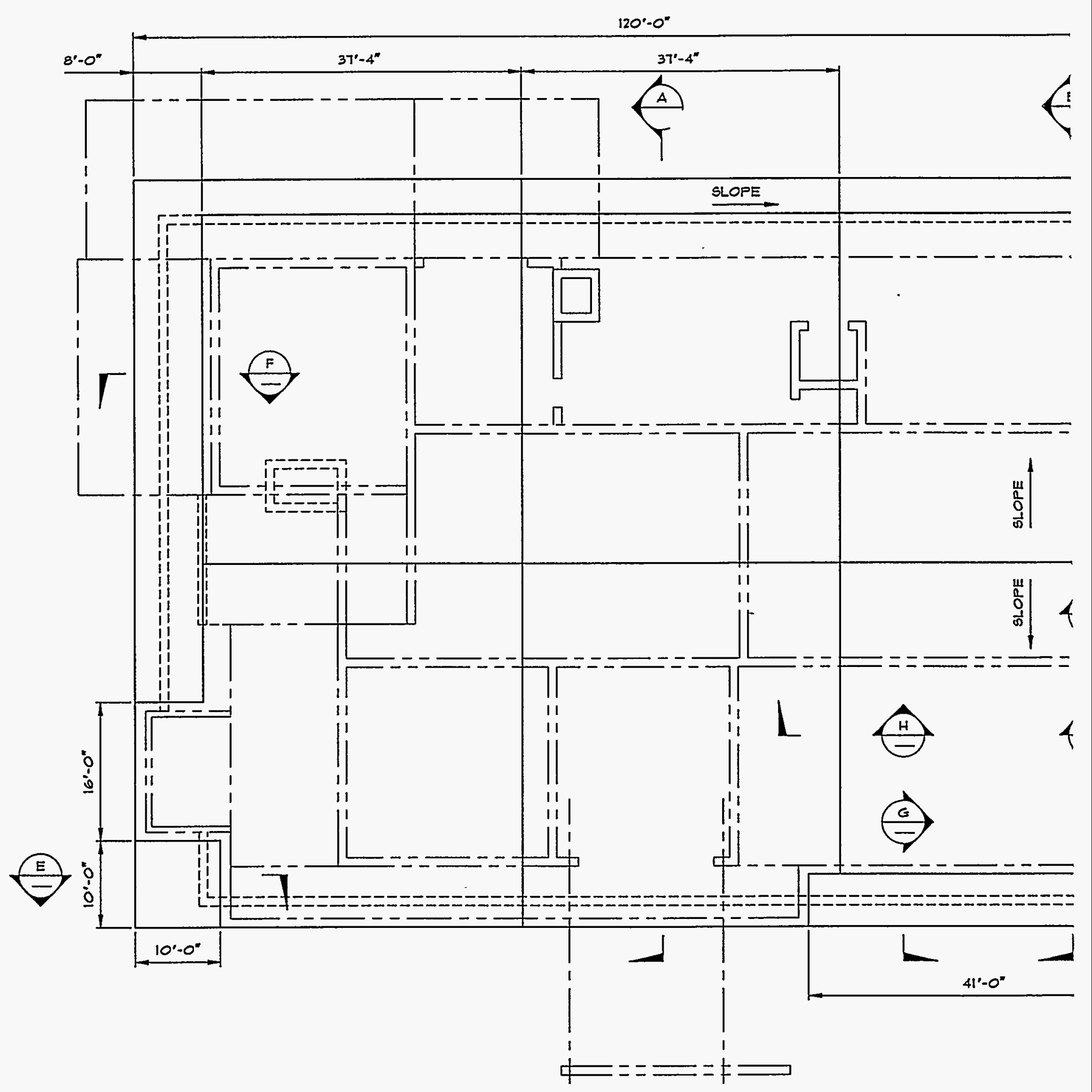

RCRA CONCRETE CAP PLAN

Figure 15. HWMA/RCRA concrete cap plan.

\begin{tabular}{l|llll|lll}
\hline 8 & 7 & 29 & 6 & 5 & 1 \\
\hline
\end{tabular}




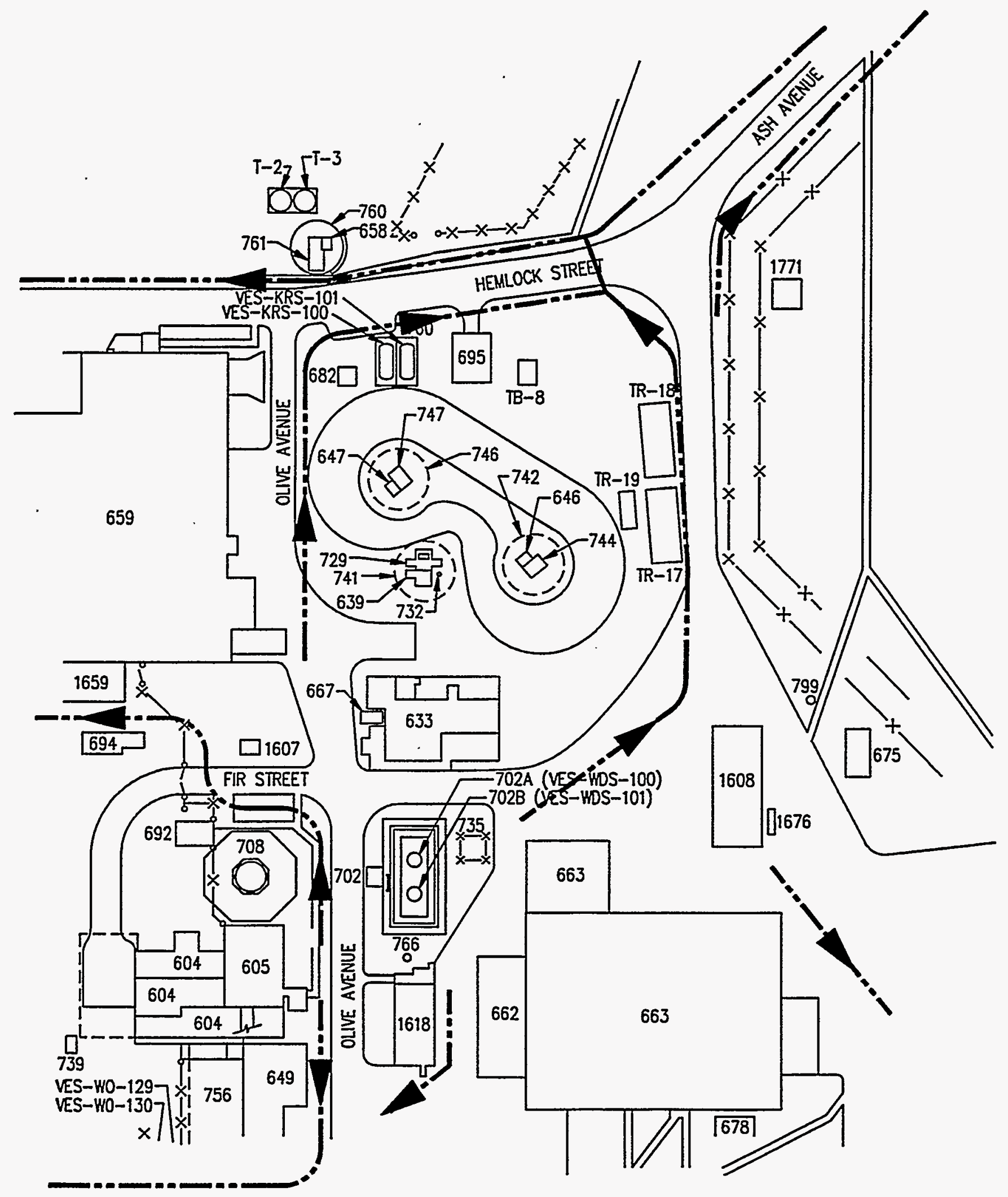

Figure 17. Storm water drains. 
from service. The liquid levels in vessel WC-119,-100, -101, -114, and -108 will continue to be monitored until grouting is initiated. The waste pile in the filter cell will be monitored for deterioration until filling the cell with grout is started. The date and rationale for termination of the HWMA Interim Status monitoring and inspection requirements for each area of the WCF will be recorded in the WCF Operating Record, which will be maintained throughout HWMA Closure. Portable safety showers and eyewash stations will be provided, maintained and inspected before and during the closure activities. Voice paging, evacuation alarms, and telephones will be maintained and inspected monthly until the cells are grouted and building demolition is started. Portable fire extinguishers will be maintained and inspected until the WCF is closed. Spill cabinets will be removed from the WCF when grouting and/or demolition begins. Temporary lighting and emergency lighting will be maintained until building demolition begins. Emergency stretchers will be maintained in the WCF until building demolition begins. Emergency equipment is inspected and maintained by the emergency response organization at ICPP and INEL, who responds to all emergencies.

\subsection{Demonstration of Closure}

\subsubsection{Closure Performance Standards}

The WCF will be closed in a manner that:

Minimizes the need for further maintenance, 'by grouting the vessels and cells to prevent subsidence, and by the construction of a low permeability concrete cap;

- Controls, minimizes, or eliminates release of hazardous constituents

- Protects human health and the environment, by the construction of a low permeability cap and plugging of external pipe lines

- Minimizes post-closure escape of hazardous waste, hazardous constituents, leachate, contaminated run-off, or hazardous waste decomposition products to the ground or surface waters or to the atmosphere, by the construction of a low permeability sloped cap, plugged external piping, and a storm water drainage system to direct run-off away from the cap

- Complies with the IDAPA 16.01.05.009 (40 CFR 265.310) closure requirements, in addition to the above, by maintaining the integrity of the cap, the groundwater monitoring system and the storm water management system.

\subsubsection{Describe Risk Assessment}

This summary presents the risk assessment (Rood, Smith, and Rood 1996) conducted to support closure of the WCF under HWMA and support the environmental assessment being prepared for the National Environmental Policy Act. In addition, the risk assessment provides the calculated risk after closure of the WCF. The general approach presented in Environmental Protection Agency risk assessment guidance used at INEL release sites governed by CERCLA was used. This provides for a consistent methodology in the preparation of risk assessments at both the CERCLA release sites and the risk based closure of HWMA units. Both a human health and an ecological risk assessment were performed. 
Two exposure scenarios were evaluated for human health. They were the current occupational and $30-$ year future residential exposure scenarios. The conceptual site model developed for the INEL identifies three exposure pathways (i.e., groundwater ingestion, dermal contact with contaminated groundwater, and external) for the identified receptors. For the current occupational exposure scenario, only the external exposure pathway was evaluated. For the 30-year future residential exposure scenario both the external exposure and groundwater ingestion exposure pathways were evaluated. And for ecological receptor, only the groundwater ingestion (as from a stock pond) exposure pathway was evaluated.

Four types of contaminants potentially remain in the WCF. These are: organic compounds (both volatile and semi-volatile compounds), metals (as oxides, nitrates, lead shielding, and elemental mercury used in instruments), anions, and radionuclides. The organic compounds were not included in the calculations because the initial evaluation indicated it is unlikely that they would be present after calcining at high temperatures (i.e., $500^{\circ} \mathrm{C}$ ). Process residue inventories for the remaining compounds were obtained and were converted to estimated soil concentrations based on a volume of the calciner vessel.

The risk for external exposure for both the current occupational and 30-year residential exposure scenario are less than the lower limit of the National Oil and Hazardous Substances Pollution Contingency Plan (NCP) target risk range (i.e., $10^{-6}$ ).

The groundwater transport modeling was performed in two phases. The first used conservative assumptions including no concrete cap or grout, all process residues were within the calcine vessel laying on it's side and open to the soil, and water could come in contact with the residues. The lead shielding and mercury were assumed to be in contact with the soil. Based on the results of this screening phase, the maximum predicted groundwater concentration of the RCRA hazardous constituents (i.e., non-radionuclides) and all but four radionuclides constituents indicated a risk below the lower limit of the NCP target risk range and were not evaluated any further. The four radionuclides whose predicted maximum groundwater concentrations indicate a risk within the NCP target risk range (i.e., $10^{-6}$ to $10^{-4}$ ) are $\mathrm{Np}-237, \mathrm{Pu}-239, \mathrm{Pu}-240$, and Tc-99. These four radionuclides were further evaluated using a refined groundwater transport model that took credit for the concrete cap and grout that will be placed in the WCF. The maximum predicted groundwater concentrations from the refined groundwater model indicate that risk to human health from $\mathrm{Np}$ 237, $\mathrm{Pu}-239$, and $\mathrm{Pu}-240$ are below the lower limit of the NCP target risk range and that the predicted risk from ingestion of ground water contaminated with Tc-99 at $682 \mathrm{pCi} / \mathrm{L}$ is $2 \mathrm{E}-06$. This is less than the proposed drinking water regulation concentration of $3,790 \mathrm{pCi} / \mathrm{L}$ for Tc-99.

This risk is calculated assuming the concrete cap covers the grouted WCF and on assuming the entire inventory of Tc-99 (as process residue) is located in the calciner vessel, when in actuality, it is located throughout the WCF. In addition, it is assumed that the concrete will crack and that water is then allowed to freely enter the calcine vessel, leach contaminants, and enter the unsaturated zone. This is a conservative assumption because the closure requirements for HWMA requires that the integrity of the cap will be maintained during the post-closure care period. 


\subsection{Schedule of Activities}

\subsubsection{WCF Unit Closure Schedule}

Activity

Notify State of Intent to Closure

Assemble WCF Closure Team

Initiate Closure Activities

Grout and Cap Waste Piping

Cap Installation

Survey Plat

Physical Closure Completed

Certification of Closure Submitted to the Director of the Idaho

Department of Health and Welfare

Transmit to IDWH and Butte County the "Record of Waste,"

"Notice in Deed," and "Certification of Notice"
To be completed

Day -60

Day -30

Month 0

Month 30

Month 34

Month 35

Month 36

Month 38

Month 40

\subsubsection{Request for Time Extension}

IDAPA 16.01.05.009 (40 CFR 265.113) requires completion of closure activities within 180 days. Health and safety concerns associated with high radiation levels and the complexity of grouting and capping piping, grouting the ducts, and construction of the cap will require a longer time frame for completion. Thus, an extension is being requested at this time pursuant to IDAPA 16.01.05.009 (40 CFR 265.113), as it is apparent that closure cannot be completed within the required time frame. Subsequent amendments to this closure plan may be submitted if additional time is required to complete closure because of problems encountered in grouting and/or capping the external waste piping and unexpected radioactive contamination.

\subsubsection{Amendments To The Closure Plan}

The conditions described in IDAPA 16.01.05.012 (40 CFR 270 Subpart D), "Hazardous Waste Permit Program, Changes to Permit" will be followed to implement any changes to this plan that exceed the magnitude of a Class 1 Modification. A written request will be submitted to the Director of IDHW detailing the proposed changes and the rationale for those changes. Minor changes (i.e., changes made within a work package such as the selection of a particular grout mix or technique) that do not compromise the closure requirements and/or performance standards identified in this plan, may be made without prior notification to the Director of IDHW. 


\subsection{Certification of Closure}

Within 60 days of the completion of physical closure, LITCO and DOE-ID will submit to the Director of Idaho Department of Health and Welfare (IDHW), by registered mail, a certification that the WCF a hazardous waste management unit, has been closed in accordance with the specifications in the approved closure plan. Certification of Closure will be provided by an independent Idaho registered professional engineer, LITCO, and DOE-ID. Because the WCF will be closed in accordance with the requirements applicable to a landfill, a "Notice in Deed" and survey plat will be required in addition to the other requirements under IDAPA 16.01.05.009 (40 CFR 265), "Interim Status Standards for Owners and Operators of Hazardous Waste Treatment, Storage, and Disposal Facilities, "IDAPA 16.01.05.009 (40 CFR 265 Subpart N): "Landfills."

\subsection{Survey Plat and Certification by Professional Land Surveyor}

A survey plat of the WCF and cap will be made and certified by a professional land surveyor. The outside wall of the WCF and the concrete cap will be identified on the survey plat. A benchmark will be installed in the concrete cap and tied to the ICPP permanent survey grid. The ICPP survey grid and the WCF benchmark will make it possible to accurately locate the WCF if it is required in the future. A copy of this plat will be kept in the ICPP operation record and a copy filed with the Butte County Courthouse.

\subsection{Notices}

\subsubsection{Notification of Partial Closure}

LITCO and DOE-ID will notify the Director of IDHW 60 days prior to date on which they intend to begin partial closure of the WCF to meet the requirements applicable to a landfill.

\subsubsection{Record of Wastes}

LITCO and DOE-ID will submit to the Director of IDHW and Butte County Commissioners, no later than 60 days after certification of closure, a record of the type, location, and quantity of hazardous wastes disposed within the WCF.

\subsubsection{Notice in Deed}

Within 60 days of certification LITCO and DOE-ID will, in accordance with Idaho State law, file a notation on the deed to the property or other instrument used for title search-that will in perpetuity notify any potential purchaser of the property that:

- The land has been used to manage hazardous wastes

- Its use is restricted under IDAPA 16.01.05.009 (40 CFR Subpart G) regulations

- The survey plat and record of the type, location, and quantity of hazardous wastes disposed of within each cell or other hazardous waste disposal unit of the facility as required by IDAPA 
16.01.05.009 [40 CFR 265.116 and 265.119(a)] have been filed with Butte County Commissioners and with the Director of IDHW.

\subsubsection{Certification of Notice}

LITCO and DOE-ID will submit, within 60 day of certification of closure, a signed certification that they have recorded the notation as specified in Section 4.7.3 of this plan and a copy of the document in which the notation has been place, to the Director of IDHW.

\subsection{Surveying and Recordkeeping}

The following items will be maintained in the operating record for the ICPP:

- A map containing the exact location and dimensions, including depth, of each cell with respect to permanently surveyed benchmark

- The contents of each cell and the approximate location of each hazardous waste type within each cell. 


\section{POST-CLOSURE CARE PLAN}

The Environmental Restoration Department manages the FFA/CO (CERCLA program) at the ICPP. The WCF is located approximately in the center of the WAG 3. WAG 3 contains several known release sites which may require maintenance and/or monitoring for many years in the future. The majority of the HWMA units at the INEL have managed radioactive hazardous waste and may need to be closed with waste in place, which will require post-closure care into the future. In an effort to eliminate duplication of effort and minimize costs associated with the long term maintenance and/or monitoring, the HWMA post-closure care requirements and the CERCLA post-ROD requirements will be integrated and managed under the CERCLA program.

HWMA surface impoundment, landfill, or land treatment units subject to IDAPA 16.01.05.009 (40 CFR 265.117-120) post-closure care will be managed under the CERCLA program. Prior to CERCLA assuming the post-closure care responsibility for the WCF, the HWMA units will be closed as required by the IDAPA 16.01.05.009 (40 CFR 265.110-116) closure requirements. WCF will be closed when the P.E. certifies that the waste lines have been grouted and capped and the concrete cap was installed as described in this closure plan. The WCF will be included as a site in the OU 3-13 WAG 3 Comprehensive RI/FS. In this respect, the OU 3-13 ROD will include appropriate ARARs (applicable, relevant, and appropriate requirements) under CERCLA for post-closure care requirements. Sections 5.1 through 5.8 demonstrate how CERCLA post-closure care requirements will meet substantive requirements for HWMA post-closure care requirements for WCF.

\subsection{Length of Post-Closure Care}

The length of HWMA post-closure care will be consistent with the length of time required for other CERCLA sites In the case of groundwater monitoring, the post-closure monitoring may be 30 years for the ICPP. This is consistent with established CERCLA protocols and the post-closure care will be reviewed no less often than every five years by the EPA (5-year reviews) to assure the human health and the environment are being protected.

\subsection{Security Requirements}

The cap design and grouting of the voids will prevent the causal (inadvertent) intruder from coming in contact with the hazardous and radiological constituents remaining in the WCF after closure. In addition, the ICPP will be a controlled and restricted area for the period of post-closure and possibly for the next 100 years as described in the INEL Land Use Scenarios document.

\subsection{Property Use Restrictions}

The ICPP will be a controlled industrial area for at least 100 years as outlined in the future land use document for the INEL. Institutional controls and care, if necessary will continue after the WCF post-closure care period is completed and will be restricted from residential development or access to the general public. 


\subsection{Groundwater Monitoring Program}

HWMA groundwater monitoring at ICPP began in January of 1992 to comply with IDAPA 16.01.05.009 (40 CFR 265, Subpart F) for ICPP waste: management units listed on the INEL HWMA Part A permit application. Groundwater monitoring in support of HWMA was terminated with the acceptance of the equivalent demonstration at the percolation ponds. Post-closure groundwater monitoring for the WCF will be integrated into the CERCLA groundwater monitoring requirements. This is due to it not being possible to monitor releases independent of the other CERCLA contaminants in the perched water bodies. As a result, the requirements will be defined and developed in the CERCLA Long Term Monitoring Plan for OU 3-13 Comprehensive RI/FS.

\subsection{Maintenance of Cap}

The post-closure maintenance and monitoring of the concrete cap will be conducted by the CERCLA program. The concrete cap will be inspected at least annually for cracks in each section of the cap and joints will be inspected for loss or degradation of the joint seal in between sections. If significant cracking of the cap is observed, the cracks or degradation will be repaired as soon as practical. If the joint seal is lost or degraded, significantly, the joint will be repaired according to the manufactures recommendations as soon as practical.

The cap will be maintained to prevent run-on and run-off from eroding or otherwise damaging the cover. Also, the surveyed benchmark will be protected and maintained.

\subsection{Post-Closure Contact}

The project manager for WAG 3 as named in the post-ROD, Remedial Design and Remedial Action Phase, will be the contact during the post-closure period.

\subsection{Post-Closure Notices}

The HWMA post-closure notice requirements will be satisfied by the requirements at $40 \mathrm{CFR}$ Part 373.

\subsection{Certifications of Completion of Post-Closure Care}

Successful completion of post-closure care of the WCF will be demonstrated pursuant to Section XXV 25.1 of the FFA/CO which states "Upon completion of the response action phase as described in the Action Plan for a given OU or WAG, U.S. DOE may request and the Lead Agency shall issue a Notice of Completion to U.S. DOE for that OU or WAG. At the discretion of the Lead Agency, a Notice of Completion may be issued for completion of a portion of the response action for an OU or WAG. 


\section{REFERENCES}

1. B. R. Helms, T.F. Borschel, et al., WCF Closure Comprehensive Work Plan, 1996.

2. K. N. Keck, Conceptual Cover Design for RCRA Closure of the ICPP Waste Calcine Facility CPP-633 at the INEL, INEL-95/0515, September 1995.

3. S. M. Rood, C. S. Smith, and A. S. Rood, Risk Assessment for the RCRA Closure of the Waste Calcining Facility, INEL-96-0041, February 1996.

4. Bickford and Sehlke, 1993, INEL Groundwater Monitoring Plan.

5. Listed Waste Determination Report, Environmental Characterization, WINCO-1132, June 1993.

6. R. L. Demmer and K. E. Archibald, Waste Calcine Facility Heel Volume Investigation and Calculation, September 1995.

7. Idaho National Engineering Laboratory Comprehensive Facility and Land Use Plan, DOE/ID-10514, March 1996. 
